NBSIR $75-794$

\title{
HEAT TRANSFER IN FURNACES FOR CIB COOPERATIVE PROGRAM AND HEAT BALANCE ANALYSIS OF WALL FURNACE
}

J. B. Fang and J. T. Scott

Center for Fire Research Institute for Applied Technology National Bureau of Standards

Washington, D. C. 20234

November 1975

Final Report

U.S. DEPARTMENT OF COMMERCE, Rogers C.B. Morton, Secretary James A. Baker, III, Under Secretary

Dr. Betsy Ancker-Johnson, Assistant Secretary for Science and Technology

NATIONAL BUREAU OF STANDARDS, Ernest Ambler, Acting Director 

LIST OF FIGURES. . . . . . . . . . . . . . V V

LIST OF NOMENCLATURE . . . . . . . . . . . . . vii

1. INTRODUCTION ........................... 1

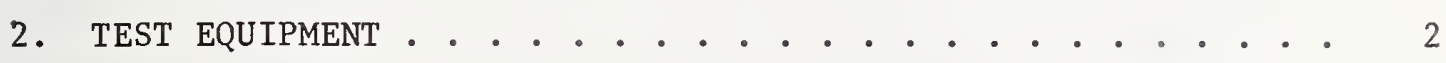

3. TEST METHOD........................ 3

3.1. Comparison of Furnaces . . . . . . . . . . 3

3.2. Heat Balance in Furnace. . . . . . . . . . 4

4. TEST RESULTS AND DISCUSSIONS ............. 4

4.1. Comparison of Furnaces . . . . . . . . . . . 4

4.2. Heat Balance in Furnace. . . . . . . . . . 5

5. REFERENCES ....................... 6

APPENDIX A. HEAT BALANCE IN FURNACE . . . . . . . . 36

APPENDIX B. A LIST OF ASSUMED PROPERTIES FOR TEST FURNACE . • 39 
Table 1. General Test Information ............ 8

Table 2. Average Heat Contribution for Test No. 1 . . . . 9

Table 3. Measured Data for Test 1........... 10

Table 4. Measured Data for Test 2........... 11

Table 5. Measured Data for Test 3........... 12 
Figure 1. Location of Radiometers and TNO Heat Flux Meters in Test Wall . . . . . . . . . . . 13

Figure 2. TNO Heat Flux Meter With Thermocouple Locations . . . 14

Figure 3. Test Wall Thermocouple Locations. . . . . . . . . 15

Figure 4. Details of Wall-Testing Furnace . . . . . . . 16

Figure 5. Upper TNO Heat Flux Meter Readings. . . . . . . 17

Figure 6. Lower TNO Heat Flux Meter Readings in Test No. 1. . . 18

Figure 7. Upper TNO Heat Flux Meter Readings in Test No. 2. . . 19

Figure 8. Lower TNO Heat Flux Meter Readings in Test No. 2. . . 20

Figure 9. Upper TNO Heat Flux Meter Readings in Test No. 3. . . 21

Figure 10. Lower TNO Heat Flux Meter Readings in Test No. 3. . . 22

Figure 11. Furnace Temperatures in Test No.1......... 23

Figure 12. Furnace Temperatures in Test No. 2. . . . . . . 24

Figure 13. Furnace Temperatures in Test No. 3. . . . . . . 25

Figure 14. Stack and Wall Temperatures in Test No. 1 . . . . 26

Figure 15. Stack and Wall Temperatures in Test No. 2 . . . . 27

Figure 16. Stack and Wall Temperatures in Test No. $3 . . . . . .28$

Figure 17. Radiometer Readings in Test No. 1 . . . . . . . 29

Figure 18. Radiometer Readings in Test No. 2......... 30

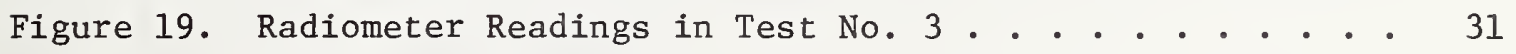

Figure 20. Inlet Air and Exhaust Gas Velocities in Test No. 1. . 32

Figure 21. Calculated Heat Input and Output Curves for NBS Wall Furnace Using a Lightweight Masonry Block Test Wall (Test No. 1)............. 33 
LIST OF FIGURES, (cont'd)

Page

Figure 22. Comparison of Calculated Radiant Heat Flux Incident at Furnace Walls and Radiant Flux Measurement (R-2) on Test Wall for Test No. 1. . . . . . . . . .

Figure 23. Schematic Diagram of Furnace and Heat Transfer . . 
$A_{B} \quad$ Interior surface area of furnace including test specimen

$A_{E}$ Cross-sectional area of the exhaust stack

$A_{S} \quad$ Interior surface area of the test specimen

$A_{w}$ Surface area of the furnace walls

$\mathrm{C}_{\mathrm{A}}$ Heat capacity at constant pressure for air

$\mathrm{C}_{i}$ Heat capacity at constant pressure for the i-th species

$\mathrm{C}_{\mathrm{V}}$ Heat capacity at constant volume for furnace gas mixture

$E_{t} \quad$ Total energy contained in furnace gases

h Convective heat transfer coefficient

$\mathrm{H}_{\mathrm{A}}^{\circ} \quad$ Enthalpy of the inlet air at the datum temperature $\mathrm{T}_{\mathrm{o}}$

$H_{B} \quad$ Radiative heat flux incident at the gray surface element

$\mathrm{H}_{\mathrm{F}}^{\circ} \quad$ Enthalpy of fuel gas at the datum temperature $\mathrm{T}_{\mathrm{o}}$

$\mathrm{H}_{i} \quad$ Enthalpy of the i-th species at temperature $\mathrm{T}$

$H_{i}^{\circ} \quad$ Enthalpy of the $i-t h$ species at the datum temperature

$M_{i}$ Molecular weight of the i-th species

$Q_{B} \quad$ Heat loss to both test specimen and furnace walls

$Q_{C} \quad$ Heat loss to both test specimen and furnace walls by convection

$Q_{F} \quad$ Heat supplied by fuel combustion

$\mathrm{Q}_{\mathrm{L}} \quad$ Heat loss to the bounding surfaces

$Q_{R} \quad$ Heat loss to both test specimen and furnace walls by radiation

$Q_{S} \quad$ Heat loss to test specimen

$\mathrm{Q}_{\mathrm{W}} \quad$ Heat loss to furnace walls

T Absolute temperature

$\mathrm{T}_{\mathrm{B}} \quad$ Temperature of exposed walls including test specimen

$T_{E} \quad$ Temperature of exhaust gases 
LIST OF NOMENCLATURE, (cont'd)

$\mathrm{T}_{\mathrm{I}} \quad$ Temperature of inlet air

$\mathrm{T}_{\mathrm{M}} \quad$ Temperature of furnace gases

To Datum temperature

$\mathrm{T}_{\mathrm{S}} \quad$ Surface temperature of the test specimen

t Time variable

$U_{E} \quad$ Velocity of exhaust gases

$\mathrm{V} \quad$ Volume of furnace

${ }_{A}{ }_{A}$ Mass flow rate of the inlet air

${ }_{F}$ Mass flow rate of fuel gas

$w_{i}$ Mass flow rate of the $i-t h$ species

$x_{i}$ Mole fraction of the $i-t h$ species

$\alpha_{B} \quad$ Absorptivity of gaseous mixture at $T_{M}$ for radiation emitted from interior walls at $\mathrm{T}_{\mathrm{B}}$

$\alpha_{S}$ Total absorptivity of the furnace gases to be evaluated at the surface temperature of the test specimen

$\alpha_{W}$ Total absorptivity of the furnace gases to be evaluated at the surface temperature of the furnace walls

$\varepsilon \quad$ Effective surface emissivity of furnace walls including test specimen

$\varepsilon_{B} \quad$ Surface emissivity of furnace walls including test specimen

$\varepsilon_{\mathrm{M}} \quad$ Emissivity of gaseous mixture

$\varepsilon_{S} \quad$ Surface emissivity of the test specimen

$\rho_{M}$ Density of gaseous mixture

$\sigma \quad$ Stefan-Boltzmann constant 
HEAT TRANSFER IN FURNACES FOR CIB COOPERATIVE PROGRAM AND HEAT BALANCE ANALYSIS OF WALL FURNACE

\section{J. B. Fang and J. T. Scott}

Tests were conducted in the NBS wall panel furnace as part of a CIB international cooperative program to measure and compare heat transfer in fire endurance furnaces. Additionally, a heat balance analysis showed that a cellular concrete block wall specimen absorbed more heat by convection than by radiation. The rate of radiant heat transfer was found to decrease slowly, while the furnace exhaust heat loss increased during the test from 42 to 58 percent of the heat output. The calculated radiant heat fluxes incident at furnace walls was found to be somewhat lower than the experimental values measured at the test wall.

Key words: Fire resistance ratings; fire test furnace; heat balance; heat transfer; temperature-time curve.

\section{INTRODUCTION}

These preliminary tests were performed as part of a cooperative effort to correlate the fire resistance of reference specimens obtained by various testing laboratories. This project was initiated following the ninth meeting of CIB (Conseil International du Bâtiment) Commission W.14 in Paris in May 1970 where it was decided to continue the work on the comparison of the performances of fire test furnaces.

Previous efforts to compare furnaces had shown wide variability among laboratories in fire resistance determinations for ratings up to 90 minutes. [1] $]^{1}$ Recently, Castle [2] made radiant and total heat flux measurements in several test furnaces operated in accordance with ASTM E119 method, and reported a wide variation in the radiation and convection levels to the specimen determined in these furnace environments. The primary reasons for these differences were that fuel properties and its input rate, amount of air introduced, furnace geometry, thermal properties of furnace walls and test specimen, the operating pressure, and the positions of burners and the exhaust stack, were varied among the furnaces, even though the same prescribed temperature-time curve was followed.

A method for measuring the heat transfer rate and comparing the performance of various furnaces was described by van Keulen in his report on "Comparison of Heat Transfer in Furnaces."[3] The report provided testing

${ }^{1}$ Numbers in brackets refer to the literature references listed at the end of this paper. 
and measurement details for determining heat transfer rate along with the theory for correlating test results between furnaces.

Three tests were conducted at NBS to measure the rates of heat transfer by radiation and convection using two TNO heat flux meters [3] set in a cellular concrete block wall. In these tests, measurements were restricted to heat flux into the elements separating the heated furnace from the outside.

The application of an overall heat balance concept to a wall panel furnace was first introduced by Harmathy. [4] He studied the effect of thermal properties of a test specimen on the fuel consumption in a temperature-programmed fire test furnace. Therefore, additional measurements were taken to provide information for a heat balance analysis of the wa11 panel furnace.

The intent of the thermal analysis was to provide relative indications of the level and mode of heat transfer processes taking place in the furnace, and to obtain a better understanding of the various phenomena involved in the determining of the fire endurance rating of a panel assemb1y.

\section{TEST EQUIPMENT}

A $4.9 \times 3.0 \mathrm{~m}$ ( $16 \times 10 \mathrm{ft}$ ) high test wall was constructed of precast cellular concrete blocks. The blocks were $22.9 \times 45.7 \times 15.2 \mathrm{~cm}$ (9 x 18 $\mathrm{x} 6 \mathrm{in})$ in size, had a density of $0.50 \mathrm{~g} / \mathrm{cm}^{3}\left(31 \mathrm{lbs} / \mathrm{ft}^{3}\right)$ and a thermal conductivity of $0.117 \mathrm{~W} / \mathrm{m}-{ }^{\circ} \mathrm{K}\left(0.0675 \mathrm{Btu} / \mathrm{hr}-\mathrm{ft}-{ }^{\circ} \mathrm{F}\right)$. The test wall had two TNO heat flux meters and two radiometers built into it as shown in figure 1. The radiometers were commercial water-cooled 150 degree viewing angle instruments of the Gardon circular foil type with a saphire window to measure the radiant heat flux component.

The TNO heat flux meters were constructed of refractory sillimanite. Two identical slabs were joined to form a $19.5 \mathrm{x} 30 \mathrm{x} 3 \mathrm{~cm}$ thick (7.7 x $11.8 \times 1.2 \mathrm{in}$ ) heat flux meter. The exposed surface of the meter was enameled and one-half of it treated with a gold paste in order to provide a difference in emissivity between the two halves. Three thermocouples were imbedded in each half of the meter while additional thermocouples monitored the temperature $5 \mathrm{~cm}$ in front of the exposed surface and $5 \mathrm{~cm}$ behind the unexposed side of the heat flux meter. All thermocouples were of $0.5 \mathrm{~mm}$ diameter chromel-alumel wires. A diagram of thermocouple locations is shown in figure 2 .

The furnace temperature was measured by 12 metallic sheathed mineral insulated fast response thermocouples symmetrically arranged within the furnace and $10 \mathrm{~cm}$ from the test specimen to provide an approximation of its average temperature. These thermocouples comprised $1 \mathrm{~mm}$ diameter chromel and alumel wires insulated with magnesium oxide from a closed end $6.4 \mathrm{~mm}$ (1/4 in) OD stainless steel (type 310) sheathed tube. For comparison purposes the furnace temperature was also monitored using 12 
ASTM thermocouples mounted within heavy iron pipes and symmetrically distributed $10 \mathrm{~cm}$ from the test wall. The time constants of the sheathed and the ASTM thermocouples were found to be approximately 1.2 and 6.2 minutes respectively, using a gas fired furnace maintained at a constant temperature of $900{ }^{\circ} \mathrm{C}$.

Specimen surface temperatures were measured using eight thermocouples arranged as shown in figure 3. Other temperatures monitored during the test were the furnace wall, the exhaust gas and the room temperature.

Inlet air and exhaust gas velocities were measured by means of pitot tubes in conjunction with a differential pressure transducer.

Furnace gas concentrations of $\mathrm{O}_{2}, \mathrm{CO}_{2}$ and $\mathrm{CO}$ were measured during the tests. Exhaust gas samples were taken using a stainless steel tube positioned in the exhaust stack. The gas was drawn through a trap filled with glass wool and was cooled with dry ice to remove smoke particles and water vapor. The gas was divided into three streams which passed through individual instruments of the following types: non-dispersive infrared analyzers for $\mathrm{CO}$ and $\mathrm{CO}_{2}$, and a magnetic susceptibility analyzer for $\mathrm{O}_{2}$.

Details of the wall test furnace including principal dimensions, are given in figure 4. The furnace is of the natural updraft type. The fuel was natural gas containing approximately $95 \%$ methane and having a specific gravity of 0.595 and a higher heating value of $38.5 \mathrm{~J} / \mathrm{cm}^{3}\left(1,033 \mathrm{Btu} / \mathrm{ft}^{3}\right)$. The gas composition and its thermochemical data are tabulated in table 1 along with some information on furnace walls and test specimen. This natural gas was supplied through 92 air-aspirating burners mounted in the wall opposite the specimen. The gas flow rate was measured every 5 minutes during Test No. 1 .

\section{TEST METHOD}

\subsection{Comparison of Furnaces}

To promote uniform test conditions the test wall was dried during Test No. 1. The ISO R-834 standard time-temperature curve was followed for one hour. The furnace was left closed until it cooled down in order to avoid water uptake in the test wall.

Two tests were then conducted in the wall panel furnace with Test No. 2 being of 60 -minute duration and Test No. 3 being a 90-minute test. A constant pressure of $1.5 \mathrm{~mm}$ of water column was maintained at a height of $2.3 \mathrm{~m}$ above the bottom of the test wall during both tests. Periodic recordings were made of various instruments on a data logger and later processed and plotted by computer. 
A description of the method and equations used for the heat balance calculations are given in appendix A. Determination of the terms in the heat balance equation were made by experimental measurements and by calculations using developed heat transfer formulae. The results of the fully instrumented first test were used for the heat balance analysis.

\section{TEST RESULTS AND DISCUSSIONS}

\subsection{Comparison of Furnaces}

The variations of temperature readings of TNO heat flux meters with time for each test are shown in figures 5 to 10 . It can be seen that the temperature of furnace gases near the meters was considerably higher than the exposed surface temperature throughout the test. Figures 11 to 13 illustrate time sequence of average furnace gas temperature measured during the tests along with the ISO R-834 standard curve plotted for comparison. An inspection of these figures show a significant difference in the temperatures measured using sheathed versus ASTM thermocouples. The results indicate over a $100{ }^{\circ} \mathrm{C}$ difference between the temperatures measured after 20 minutes during Test No. 1 with similar results obtained in the other tests. This temperature difference was attributed to high thermal capacitance of the iron protection tubes utilized in ASTM thermocouples and significant radiation loss from the tubes to the cooler furnace walls.

The average surface temperatures of furnace walls and the test specimen, and the flue gas in the exhaust stack for the three tests are shown in figures 14 to 16 as a function of time. It is important to note that the surface temperature of the test specimen was approximately equal to that of furnace walls. Figures 17 to 19 show plots of radiation flux densities determined at two locations of the test specimen versus time. As shown in the figures, there was 1ittle variation in the measured radiant fluxes between tests 1 and 2 . The reason for the higher irradiance observed at the lower portion (radiometer No. 2) of the test wal1 than that at its upper part (radiometer No. 1) as shown in figure 19 was not known.

Time variations of the velocities of air entering into the furnace through the inlet ports, and combustion gases flowing inside the exhaust stack of Test No. 1 are given in figure 20. The results of gas analysis demonstrated that a process of complete combustion of fuel gas occurred in the test furnace since no $C O$ was detected in flue gas. The concentrations of $\mathrm{CO}_{2}$ and $\mathrm{O}_{2}$ in the exhaust stream were found to be relatively constant after approximately 10 minutes after the start of the test. The flue gas composition averaged over the last 50 minutes of the test was $8.7 \% \mathrm{CO}_{2}, 8.4 \% \mathrm{O}_{2}$ and $82.9 \% \mathrm{~N}_{2}$ (dry basis).

The test results tabulated in tables 3 through 5 were forwarded to van Keulen for data analysis with the other participating laboratories. Summary data of the test series were given in his report along with 
construction details of TNO heat flux meter, and the procedure for furnace performance evaluation. [5] He compared the performance of each test furnace based on the amount of heat accumulated in the standardized wall test material versus time curve, and concluded that a correction factor to reduce differences between furnaces was not presented due to wide scattering of test results, and insufficient data for justification. The determination of separate contributions of radiation and convection components to the heating of the test specimen was unsuccessful because of evaporation of the gold coating on TNO heat flux meters.

\subsection{Heat Balance in Furnace}

Using the equations developed in appendix $A$, determinations were made of the heat input and output terms. Figure 21 provides a graph of each term in the heat balance equation. Inspection of the curves showed a decreasing rate of heat supply from the fuel while there was a slight increase in heat loss through the exhaust stack. Convective and radiative heat losses decreased during the test. The sensible energy supplied by the inlet air and the heat stored in the furnace gases were very small and were neglected.

The determined convective heat transfer coefficient, $h$, ranged from 89 to $180 \mathrm{~W} / \mathrm{m}^{2}-{ }^{\circ} \mathrm{C}\left(16\right.$ to $\left.32 \mathrm{Btu} / \mathrm{hr}-\mathrm{ft}^{2}-{ }^{\circ} \mathrm{F}\right)$. These $\mathrm{h}$ values seem to be comparable with values determined by other experiments. [6] A check of the convective and radiant heat transfer throughout the test with the calculated $h$ values, assumed thermal properties of furnace wall material as given in appendix $\mathrm{B}$, and measured furnace gas temperatures using a method described in reference 7 showed that the deviation between the estimated average surface temperature of the furnace walls and the actual measured value varied from 0.2 to $11.3 \%$ with an average of $3.7 \%$.

Since there were some difficulties in calibration of the oxygen analyzer, the composition and mass flow rate of combustion products were calculated based on the measured gas composition and mass rate of the fuel gas, and the concentration of $\mathrm{CO}_{2}$ in the exhaust stream. It was found that the flue gas consisted of $7.3 \% \mathrm{CO}_{2}, 14.9 \% \mathrm{H}_{2} \mathrm{O}, 5.1 \% \mathrm{O}_{2}$ and $72.7 \% \mathrm{~N}_{2}$, and the fuel burned with approximately $36 \%$ in excess of the air required for complete combustion. The total emissivity and absorptivity for furnace gases were derived from $\mathrm{H}_{2} \mathrm{O}$ and $\mathrm{CO}_{2}$ emissivity charts developed by Hottel and his coworkers [8] with a correction to account for spectral overlap of emission bands. The gas emissivity was found to range from 0.30 to 0.22 , decreasing with an increase in gas temperature, and the absorptivity varied between 0.33 and 0.22 .

Listed in table 2 are the average heat transfer contributions for each of the terms in the heat balance equation along with their percentage contribution to heat input or output. For this furnace, the largest heat loss was due to the flow of hot combustion products through the exhaust stack, and this increased from $42 \%$ at 10 minutes to $58 \%$ at 60 minutes. Convective heat loss to the furnace walls was found to decrease with time from 42 to $34 \%$ of the total heat input, and the rate of radiant heat 
transferred into furnace walls was also seen to decrease gradually with increasing wall surface temperature during the test.

Figure 22 shows a comparison plot of time variation of calculated radiant heat flux incident at the furnace walls and the measured radiant flux obtained at the test wall for Test No. 1. The calculated values were computed on the basis of the rate of radiant heat loss shown in figure 21, and the average interior wall temperature using a surface emissivity of 0.8 for all furnace walls. It can be seen from the figure that the calculated values were approximately $15 \%$ less than those determined experimentally. This discrepancy in radiative heat transfer to the surface element may be due to non-uniformity of the temperature and composition of furnace gases. Also there might have been introduced some errors with higher readings on the radiometer as a result of reradiation from the heated sapphire window attachment to the foil sensing element.

The fire resistance rating of a structural element depends upon its physical and thermal properties and the heat flux incident at its bounding surfaces from the surrounding furnace walls and the furnace gas. The magnitude of the incident heat flux is determined by the furnace geometry, the surface emissivity and thermal properties of the furnace walls, the radiative properties, the gas flow and turbulence characteristics of the furnace gas as well as its temperature. The incident heat flux to the test wall appears to be a more appropriate parameter to be measured during the test than the gas temperature for characterizing and monitoring the furnace fire intensity.

The results of this study are limited to the single test which involved one material and one set of test conditions. Future testing with additional instrumentation by including water-cooled total heat fluxmeters and gas purged radiometers will make possible a verification of the results obtained. Extension to other materials of different thermal properties will provide data for better comprehension of the fire endurance testing since thermal properties determine the temperature level of the exposed surface, and the amount of heat absorbed by the test wall.

\section{REFERENCES}

[1] Correlation Tests on Furnaces for Separating Elements, Bundesantalt fer Materialprufung (BAM) Laboratory for Fire Protection, West Germany, (Jan. 1970).

[2] Castle, G. K., The Nature of Various Fire Environments and the Application of Modern Material Approaches for Fire Protection of Exterior Structural Steel in Them, AVCO Systems Division, A paper presented at A.I.Ch.E. Loss Prevention Symposium, Nov. 14, 1973, Philadelphia. 
[3] van Keulen, J., Comparison of Heat Transfer in Furnaces, paper for CIB Commission W.14, Group 1, Fire Endurance (Nov. 1971).

[4] Harmathy, T. Z., Design of Fire Test Furnaces, Fire Technology, Vo1. 15, No. 2, 140-150 (May 1969).

[5] van Keulen, J., Comparison of Heat Transfer in Several Wall Furnaces, Report of CIB Commission W.14, No. BVI-74-17 (Feb. 1974).

[6] Seigel, L. G., Effect of Furnace Design on Fire Endurance Test Results, Fire Test Performance, ASTM STP 464, 57-67 (1970).

[7] Hill, P. R., A Method of Computing the Transient Temperature of Thick Walls from Arbitrary Variation of Adiabatic-Wall Temperature and Heat-Transfer Coefficient, Nat. Advisory Committee for Aeronautics, (U.S.) Tech Note 4105 (Oct. 1957).

[8] Hottel, H. C. and Sarofim, A. F., Radiative Transfer (McGraw-Hill, New York, 1967). 
Fuel:

Gas Composition:

Specific Gravity:

Heating Value

(corrected to 14.2

${ }^{\circ} \mathrm{C}\left(60^{\circ} \mathrm{F}\right), 762 \mathrm{~mm}$

(30 in) Hg dry):
Natural Gas

$95.1 \% \mathrm{CH}_{4}, 3.0 \% \mathrm{C}_{2} \mathrm{H}_{6}, 0.76 \% \mathrm{C}_{3} \mathrm{H}_{8}$

$0.29 \% \mathrm{C}_{4} \mathrm{H}_{10}, 0.14 \% \mathrm{C}_{5} \mathrm{H}_{12}, 0.70 \% \mathrm{CO}_{2}$

$0.01 \% \mathrm{~N}_{2}$

0.595

$38.5 \mathrm{~J} / \mathrm{cm}^{3}\left(1,033 \mathrm{Btu} / \mathrm{ft}^{3}\right)$ (Gross)

$34.7 \mathrm{~J} / \mathrm{cm}^{3}\left(931 \mathrm{Btu} / \mathrm{ft}^{3}\right)$ (Net)

Furnace Walls:

Fire Brick

Test Wall:

Cellular Concrete Blocks

Density $=0.50 \mathrm{~g} / \mathrm{cm}^{3}\left(31 \mathrm{lbs} / \mathrm{ft}^{3}\right)$

Thermal Conductivity $=0.117 \mathrm{~W} / \mathrm{m}-{ }^{\circ} \mathrm{K}$

$\left(0.0675 \mathrm{Btu} / \mathrm{ft}-\mathrm{hr}-{ }^{\circ} \mathrm{F}\right)$

Gas Flow Data:

Note: For additional information see figures 1-4. 
Table 2. Average Heat Contribution for Test No. 1

\begin{tabular}{|c|c|c|c|c|c|}
\hline & \multirow[b]{2}{*}{ Term } & \multicolumn{2}{|c|}{ Rate of Heat Flow } & \multicolumn{2}{|c|}{ Percent } \\
\hline & & $\mathrm{Kw}$ & $\left(10^{6} \mathrm{Btu} / \mathrm{hr}\right)$ & Average & Range \\
\hline Energy In & $Q_{F}$ & 2,180 & 7.45 & 100 & --- \\
\hline \multirow[t]{3}{*}{ Energy Out } & $\sum\left(w_{i} H_{i}\right)$ & 1,155 & 3.95 & 53 & $42-58$ \\
\hline & $Q_{R}$ & 243 & 0.83 & 11 & $7-16$ \\
\hline & $Q_{C}$ & 782 & 2.67 & 36 & $34-42$ \\
\hline
\end{tabular}




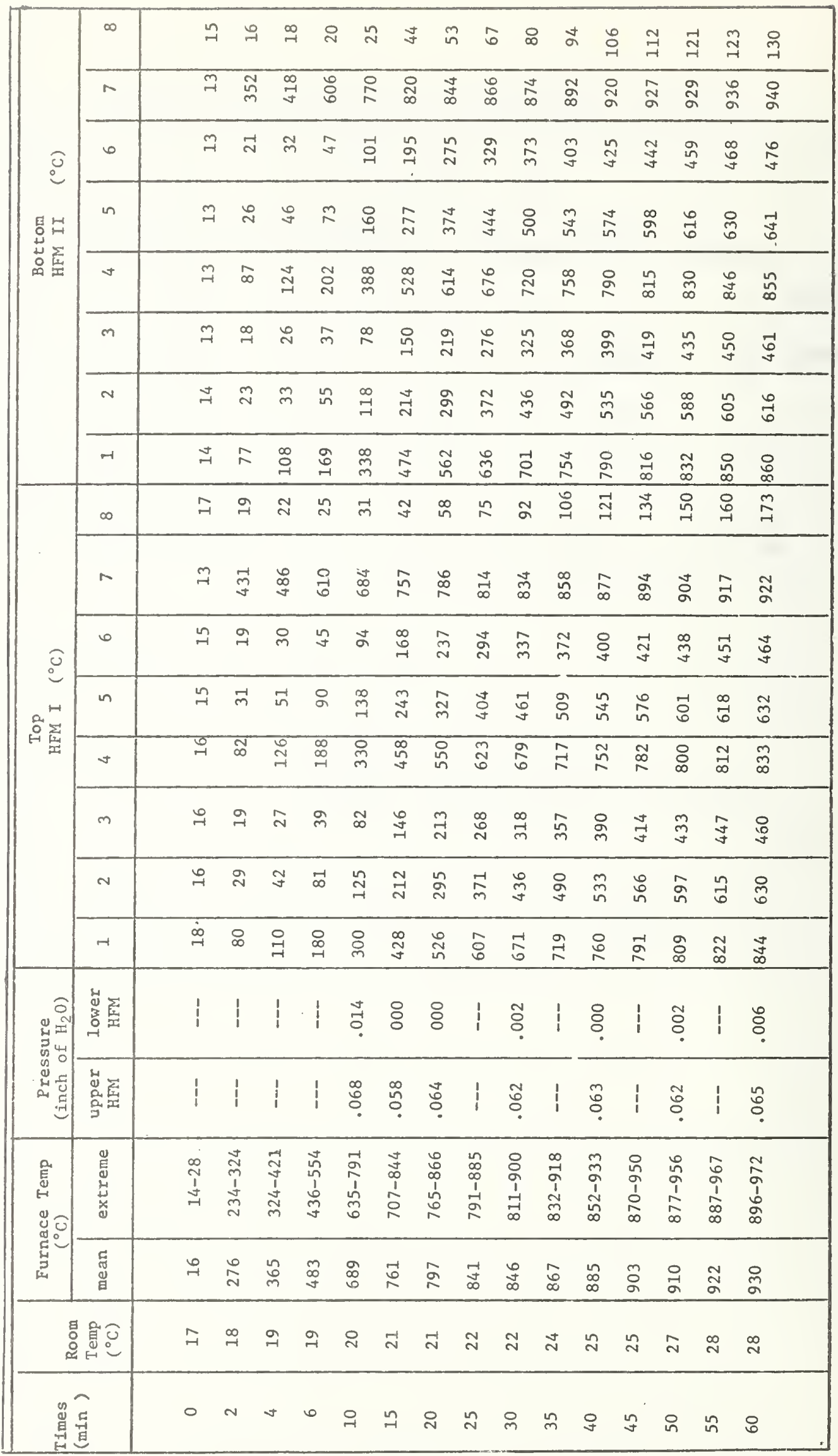




\begin{tabular}{|c|c|c|}
\hline \multirow{8}{*}{ 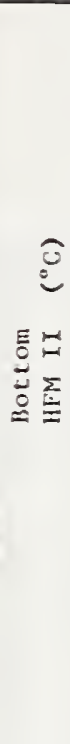 } & $\infty$ & 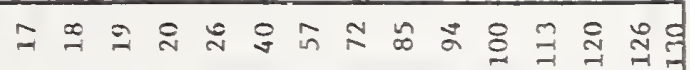 \\
\hline & r & 二 \\
\hline & $\bullet$ & ڤ \\
\hline & in & 교 \\
\hline & $\sigma$ & 二 \\
\hline & m & 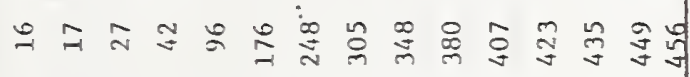 \\
\hline & n & 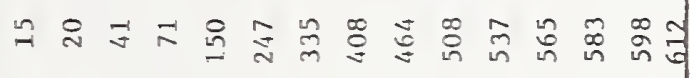 \\
\hline & -1 & 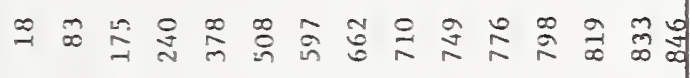 \\
\hline \multirow{8}{*}{ 尊 } & $\infty$ & 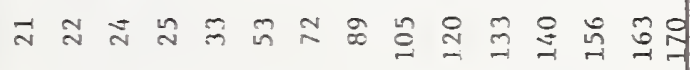 \\
\hline & $\sim$ & 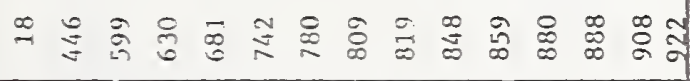 \\
\hline & 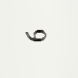 & 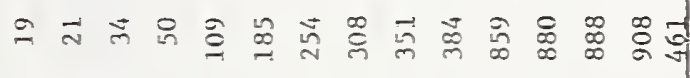 \\
\hline & n & 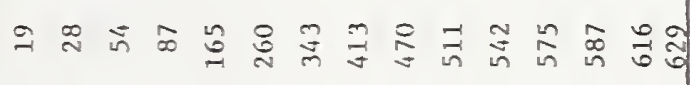 \\
\hline & $\checkmark$ & సేゅ@ \\
\hline & m & 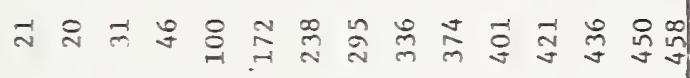 \\
\hline & n & 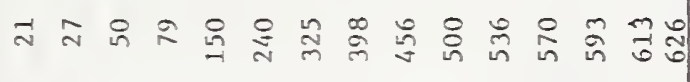 \\
\hline & -1 & $\bar{\sim}$ స \\
\hline \multirow[t]{2}{*}{ 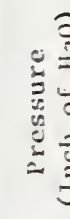 } & 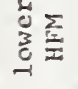 & | \\
\hline & 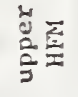 & 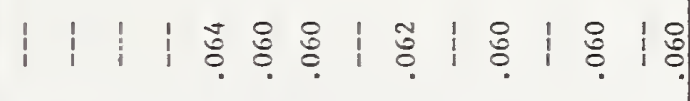 \\
\hline \multirow{2}{*}{ 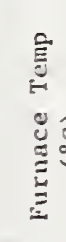 } & 芦 & 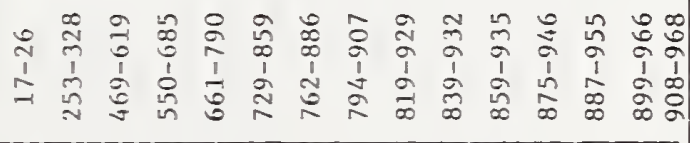 \\
\hline & $\underset{E}{\tilde{E}}$ & 잉 \\
\hline \multicolumn{2}{|c|}{ 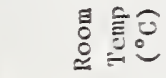 } & $\approx 2$ ㄱ. 족 \\
\hline \multicolumn{2}{|c|}{ 蒫苞 } & 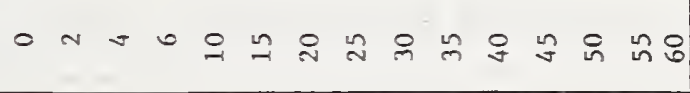 \\
\hline
\end{tabular}




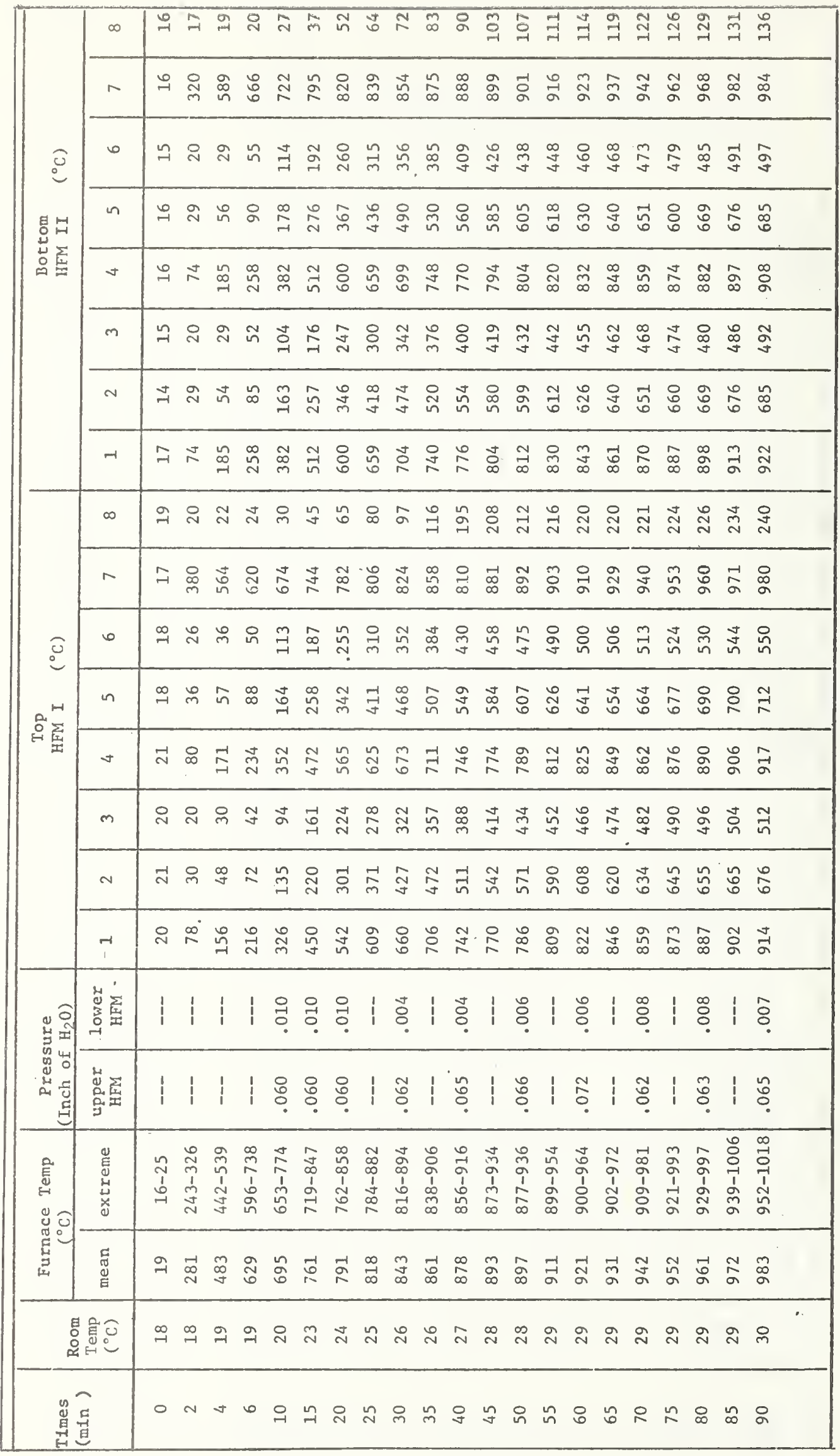




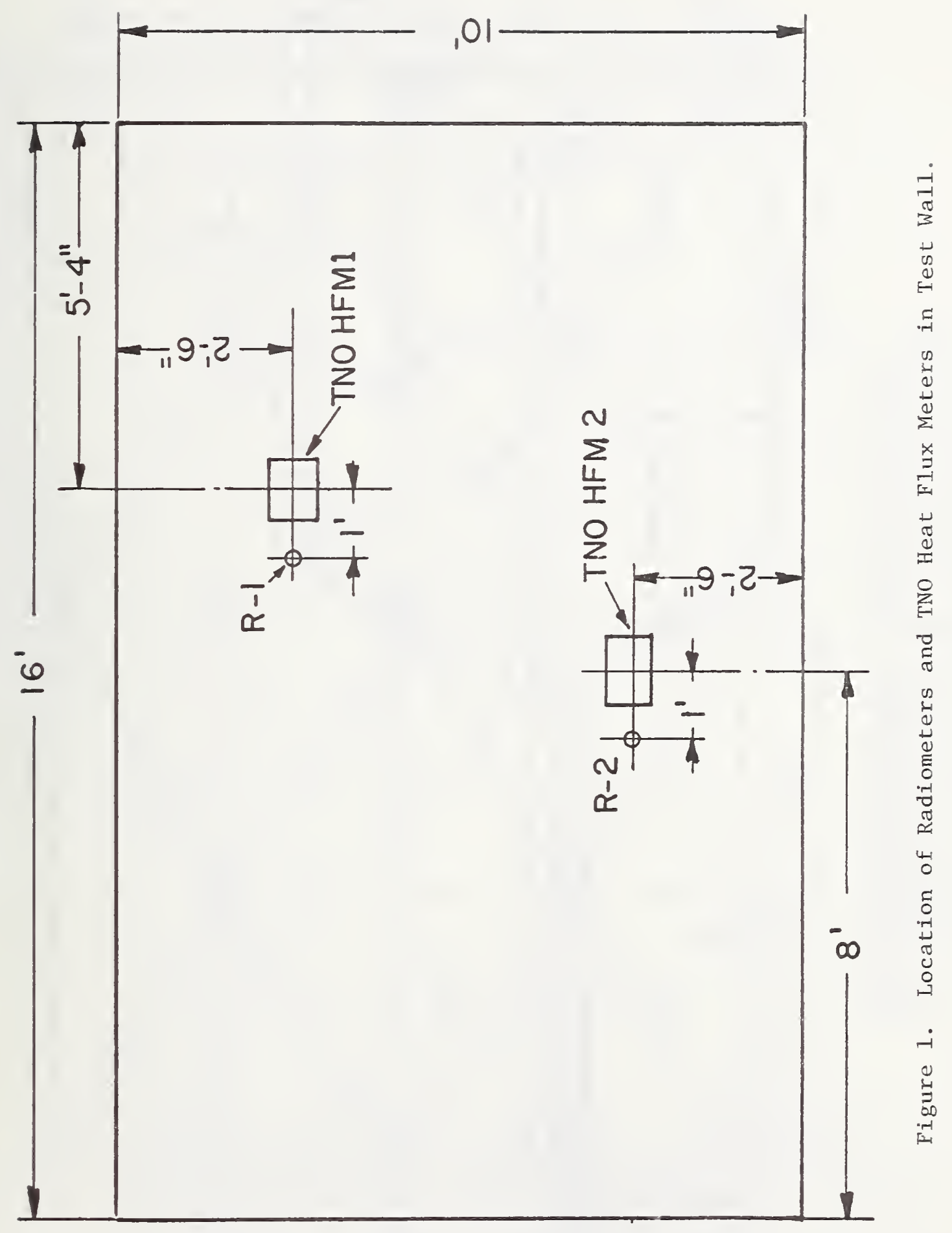




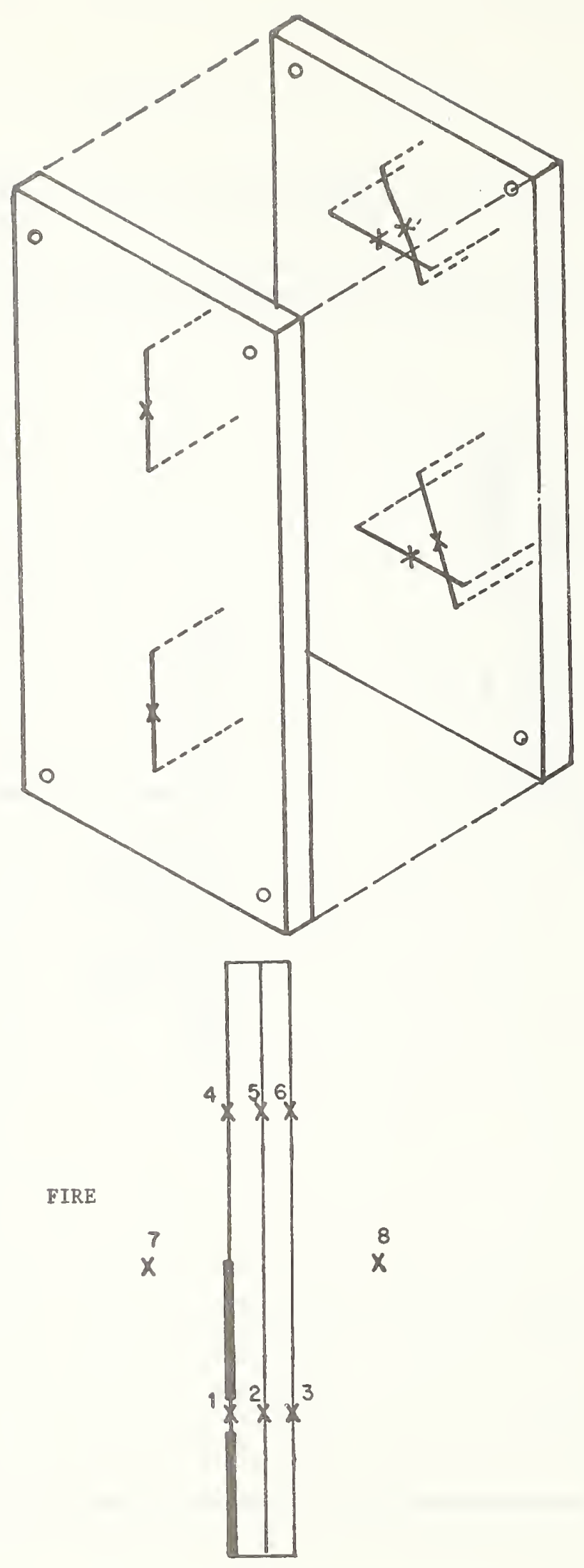

Figure 2. TNO Heat Flux Meter With Thermocouple Locations. 


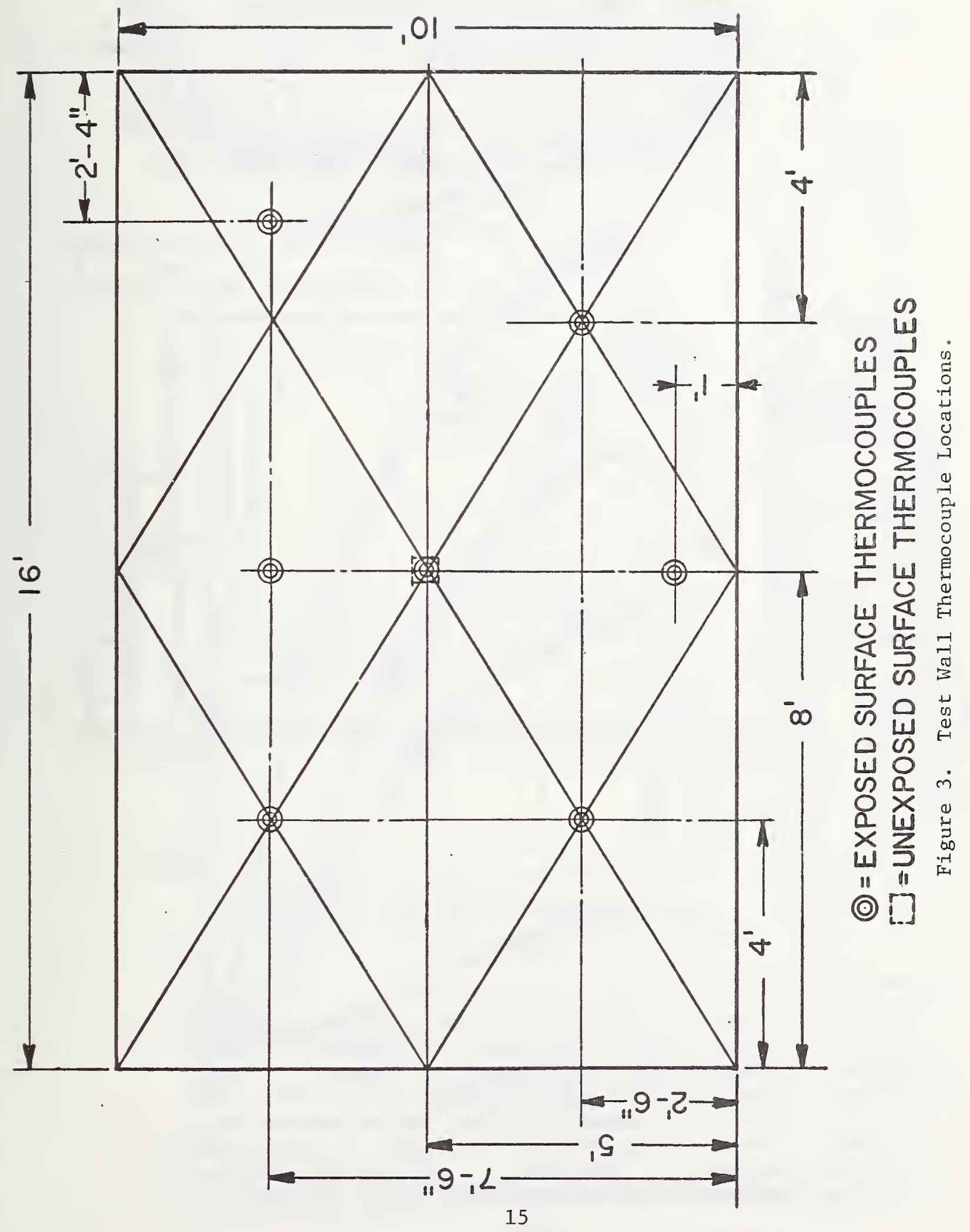




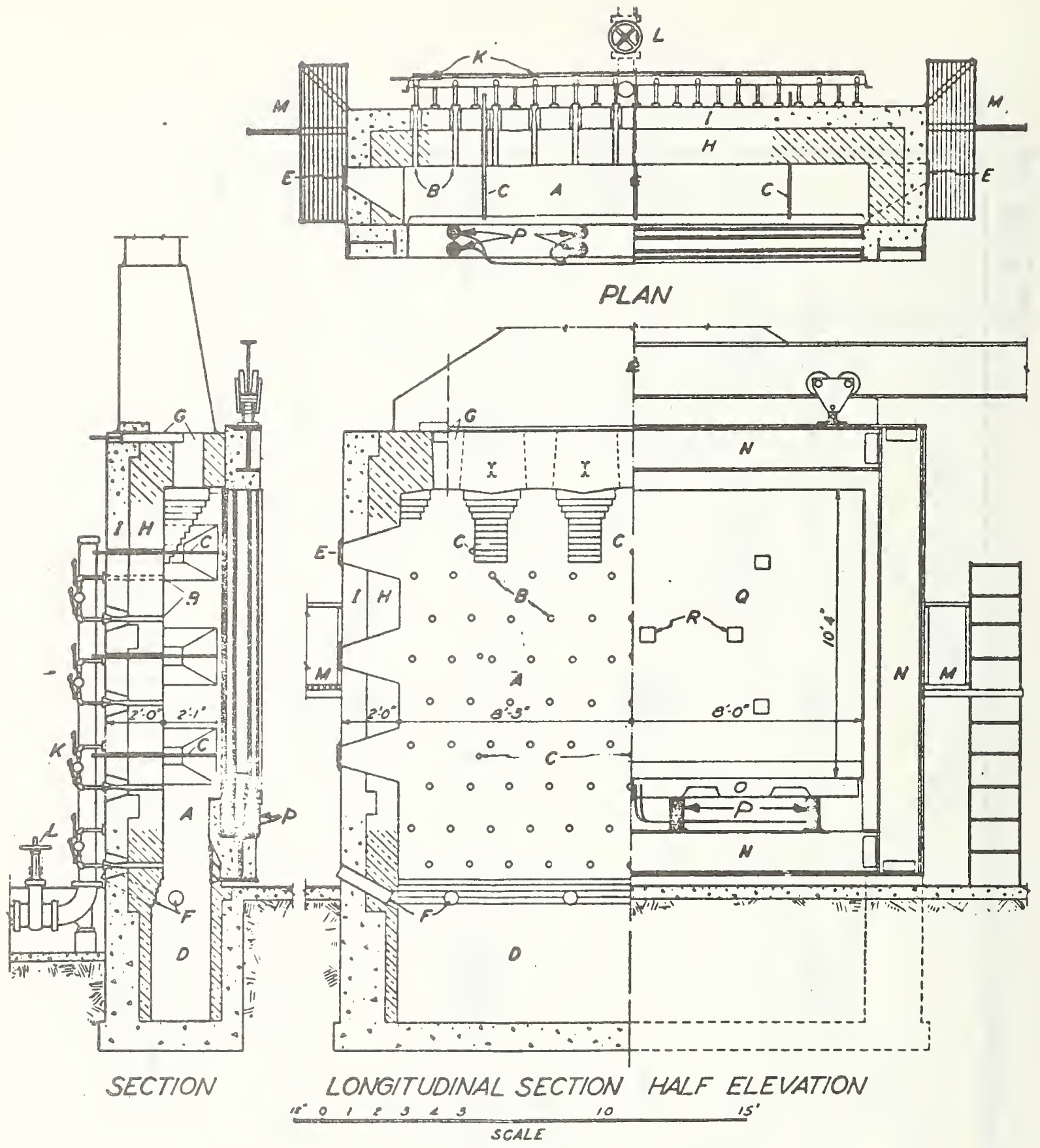

Figure 4. Details of Wa11-Testing Furnace.

A, Furnace Chamber; B, Burners; C, Thermocouple Protection

Tubes; D, Pit for Debris; E, Observation Windows; F, Air

Inlets; G, Flue Outlets and Dampers; H, Firebrick Furnace

Lining; I, Reinforced Concrete Furnace-She11; K, Gas Cocks;

L, Control Valve; M, Ladders and Platforms to Observation

Windows; N, Movable Fireproofed Test Frame; 0, Loading Beam;

P, Hydraulic Jacks; Q, Test Wall; R, Asbestos Felted Pads

Covering Thermocouples on Unexposed Surface of Test Wall. 


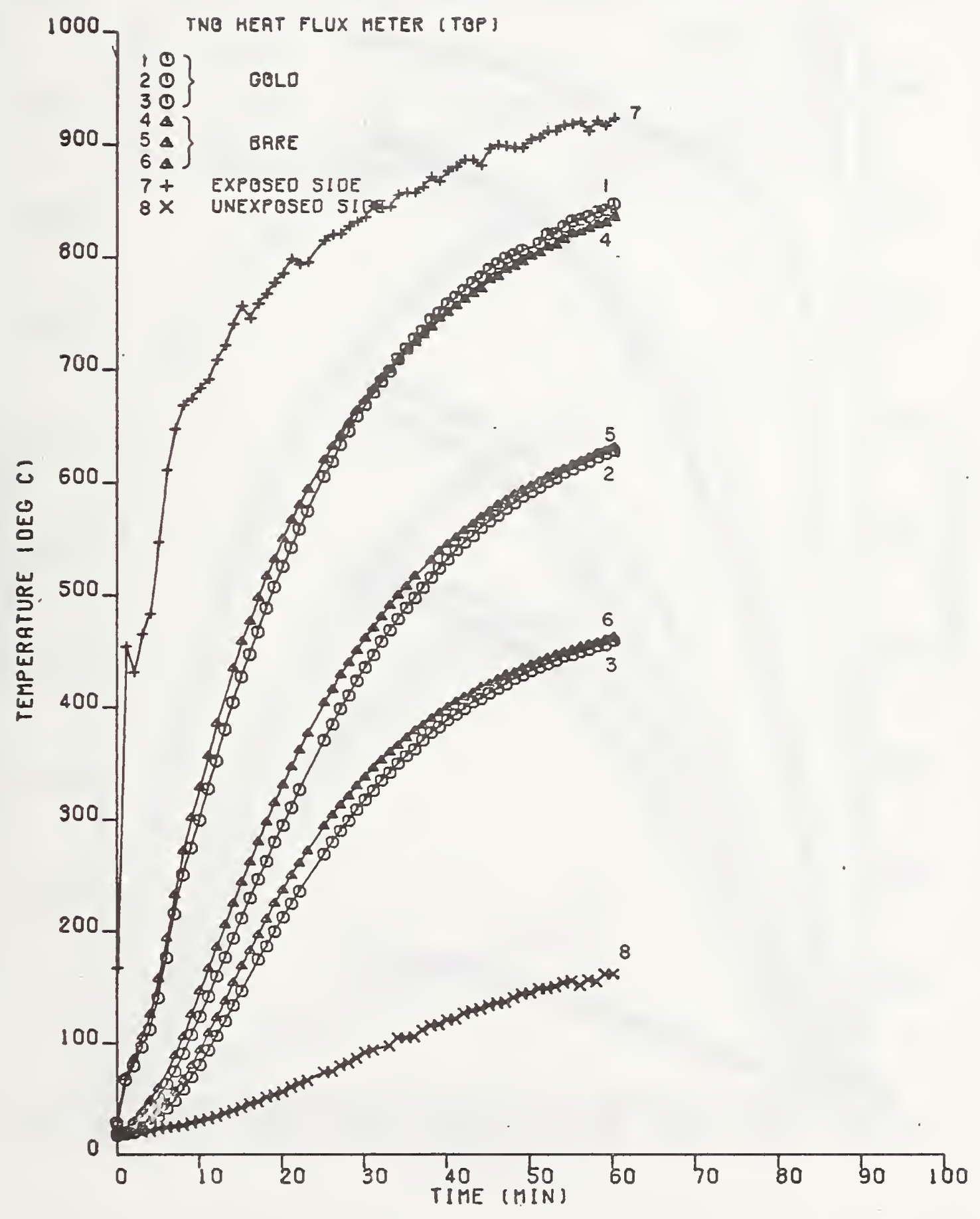

Figure 5. Upper TNO Heat Flux Meter Readings. 


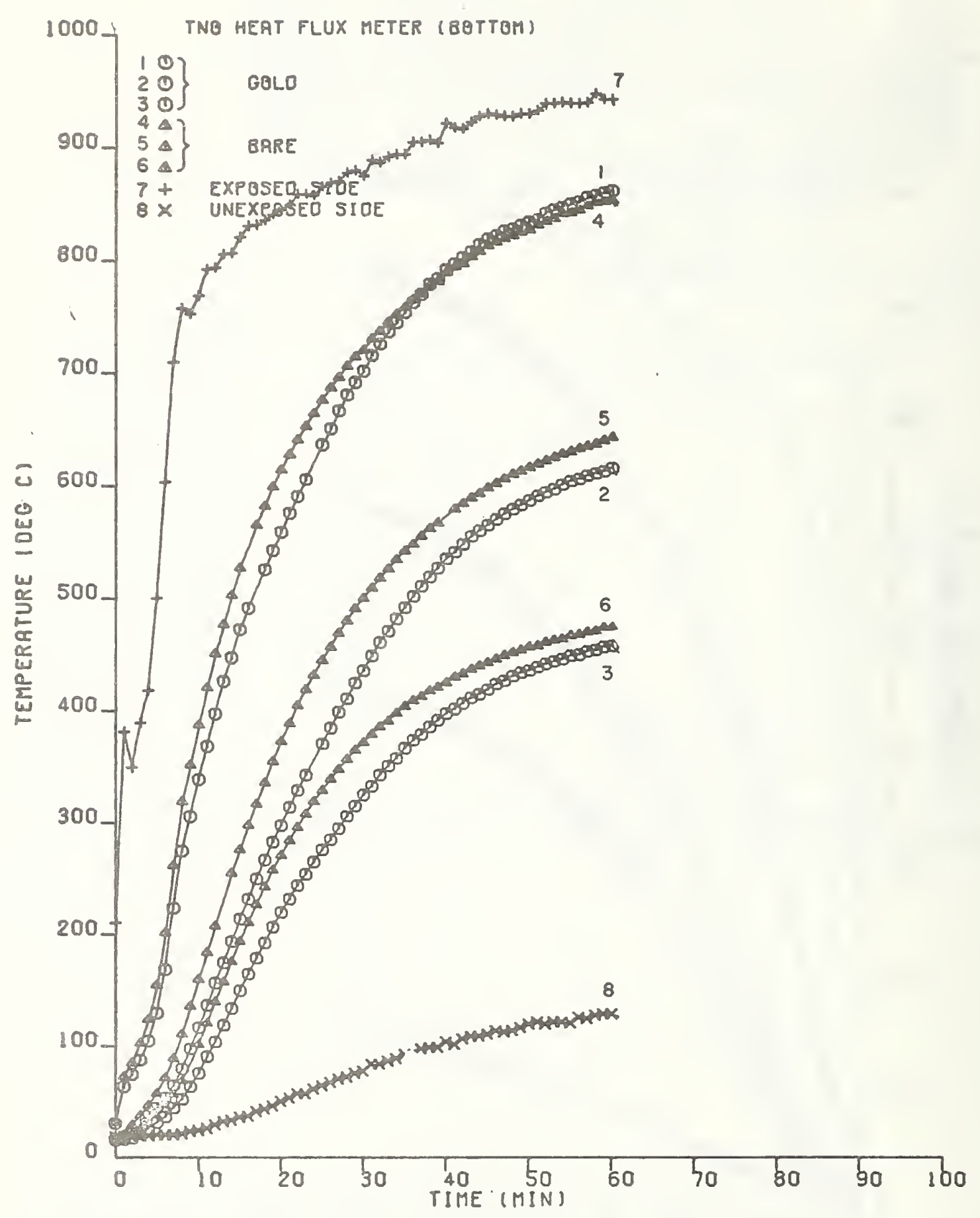

Figure 6. Lower TNO Heat Flux Meter Readings in Test No. 1. 


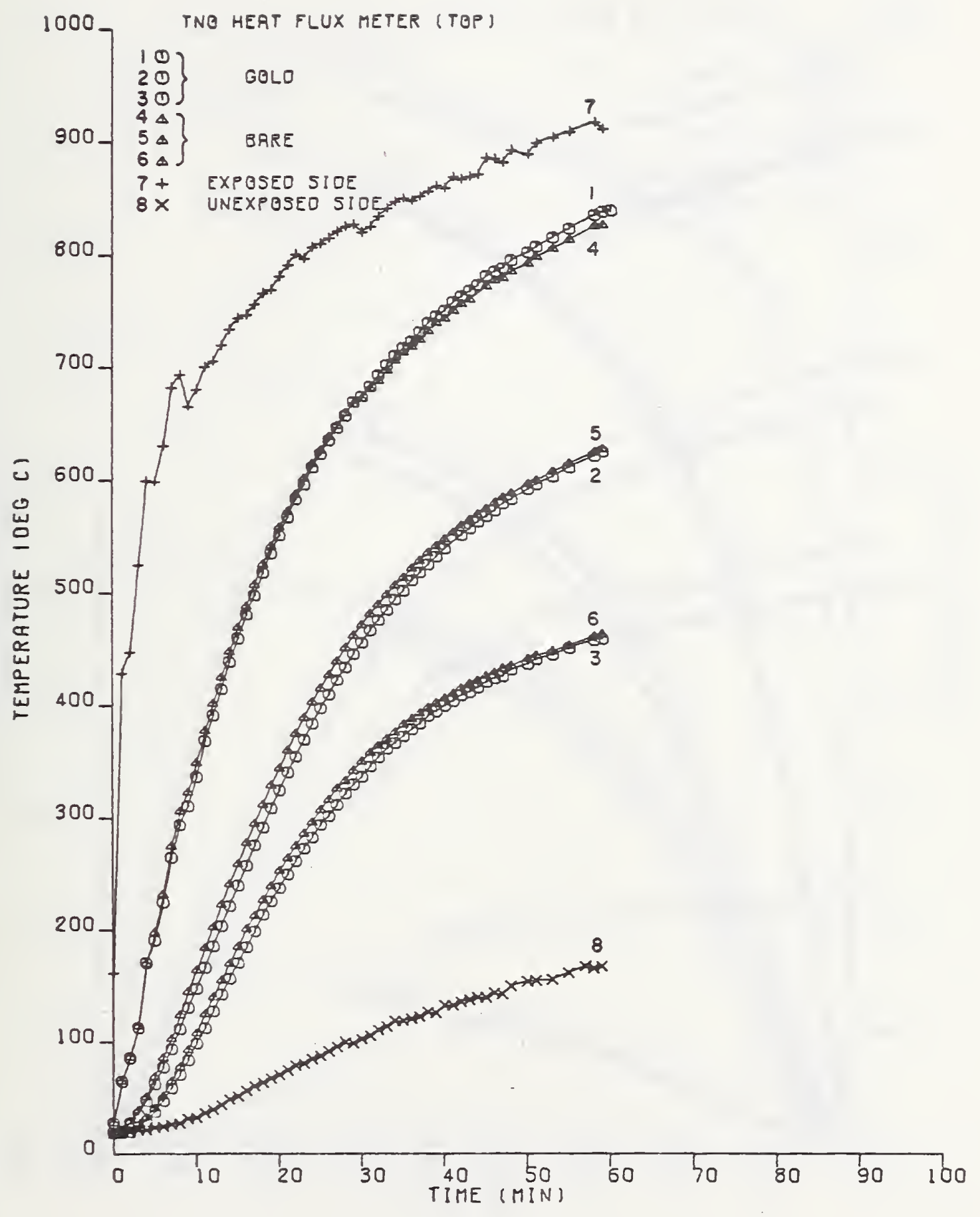

Figure 7. Upper TNO Heat Flux Meter Readings in Test No. 2. 


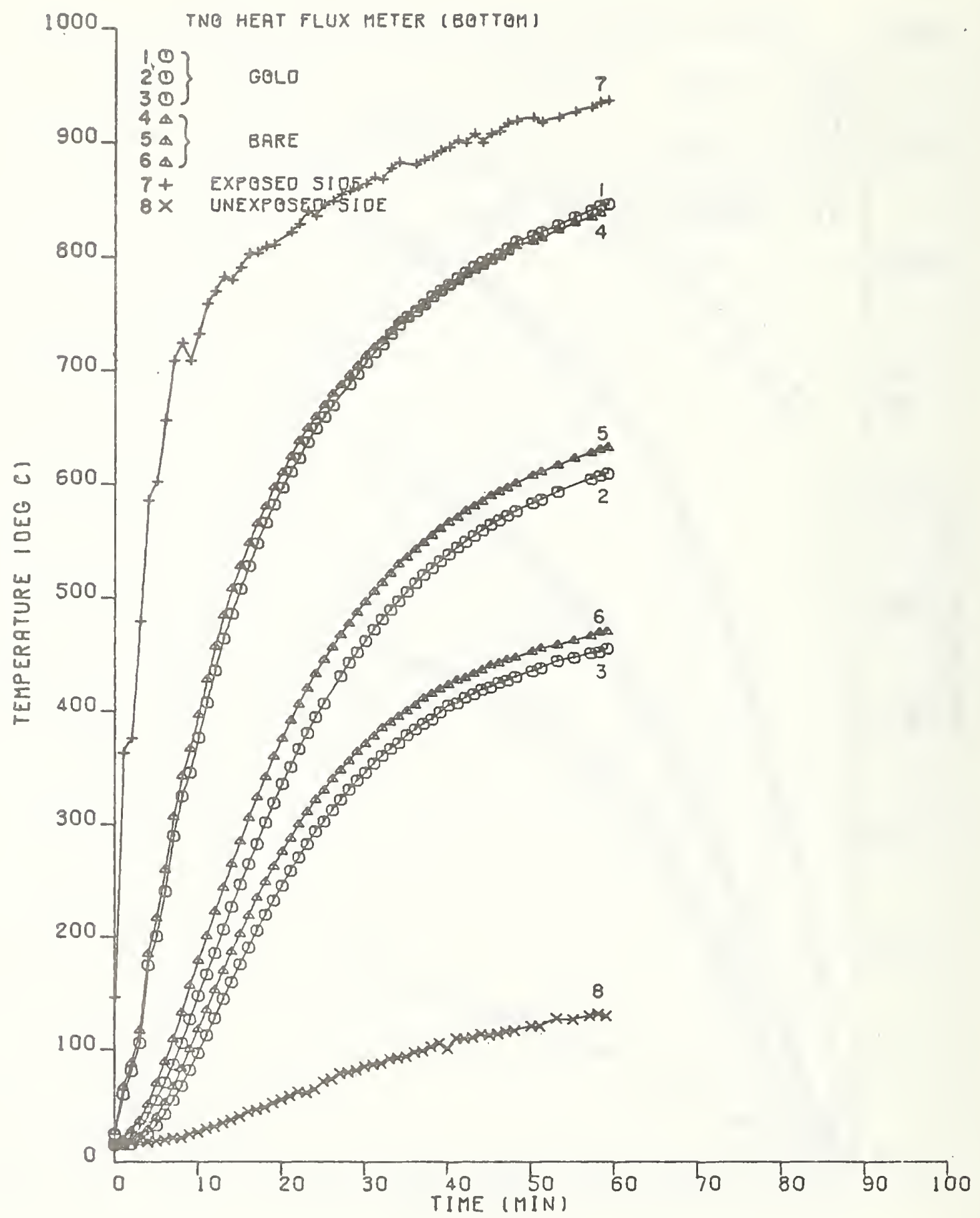

Figure 8. Lower TNO Heat Flux Meter Readings in Test No. 2. 


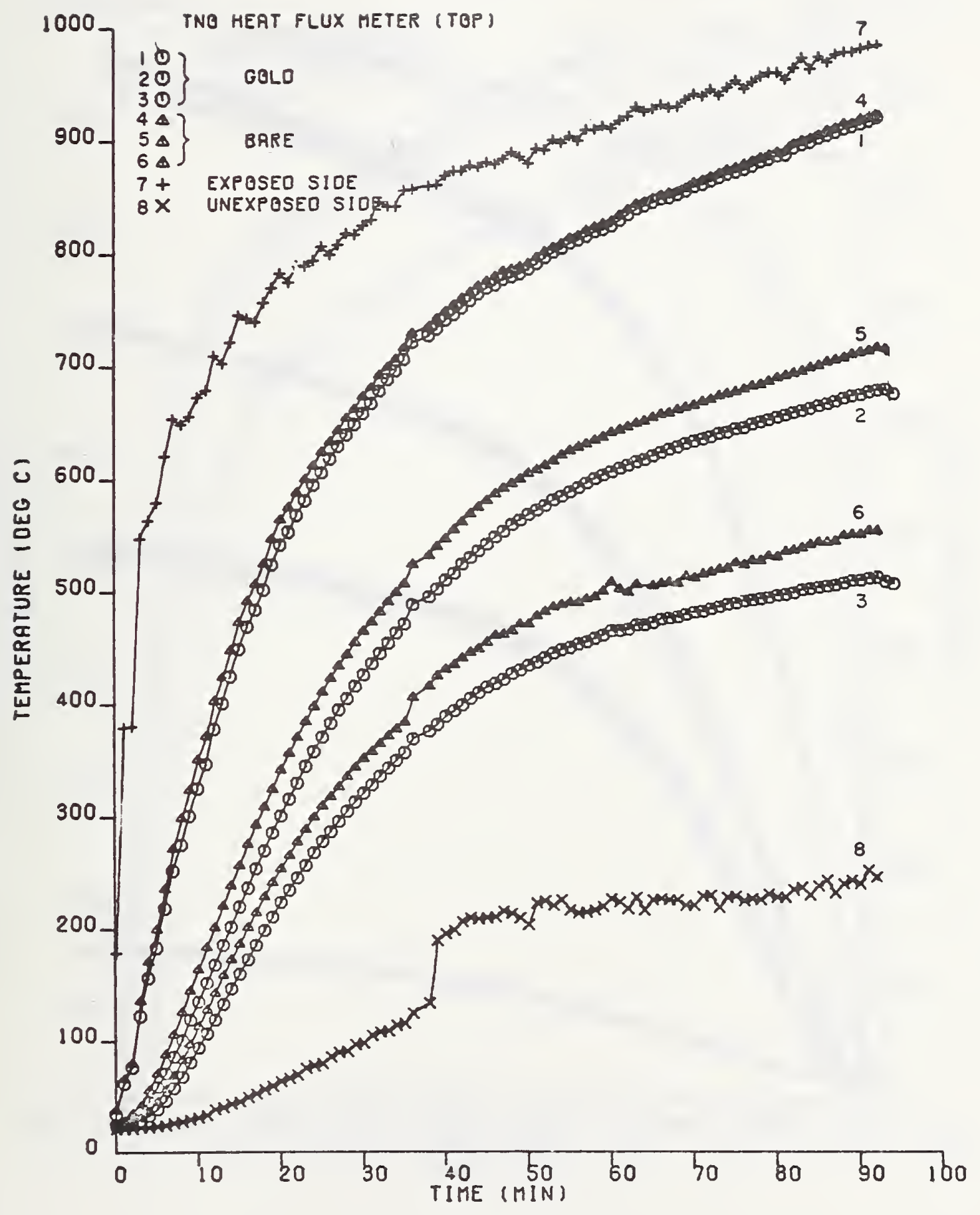

Figure 9. Upper TNO Heat Flux Meter Readings in Test No. 3. 


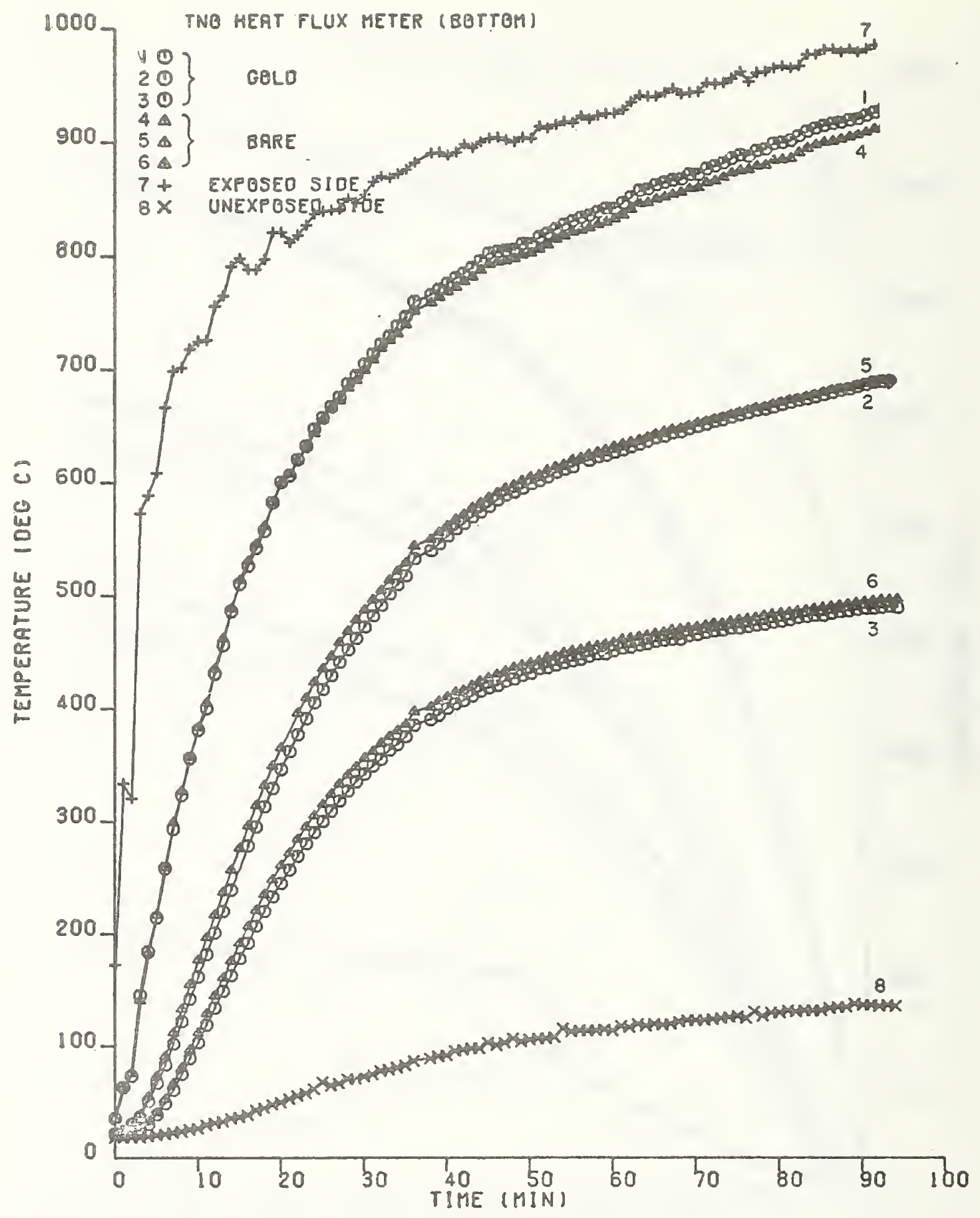

Figure 10. Lower TNO Heat Flux Meter Readings in Test No. 3. 


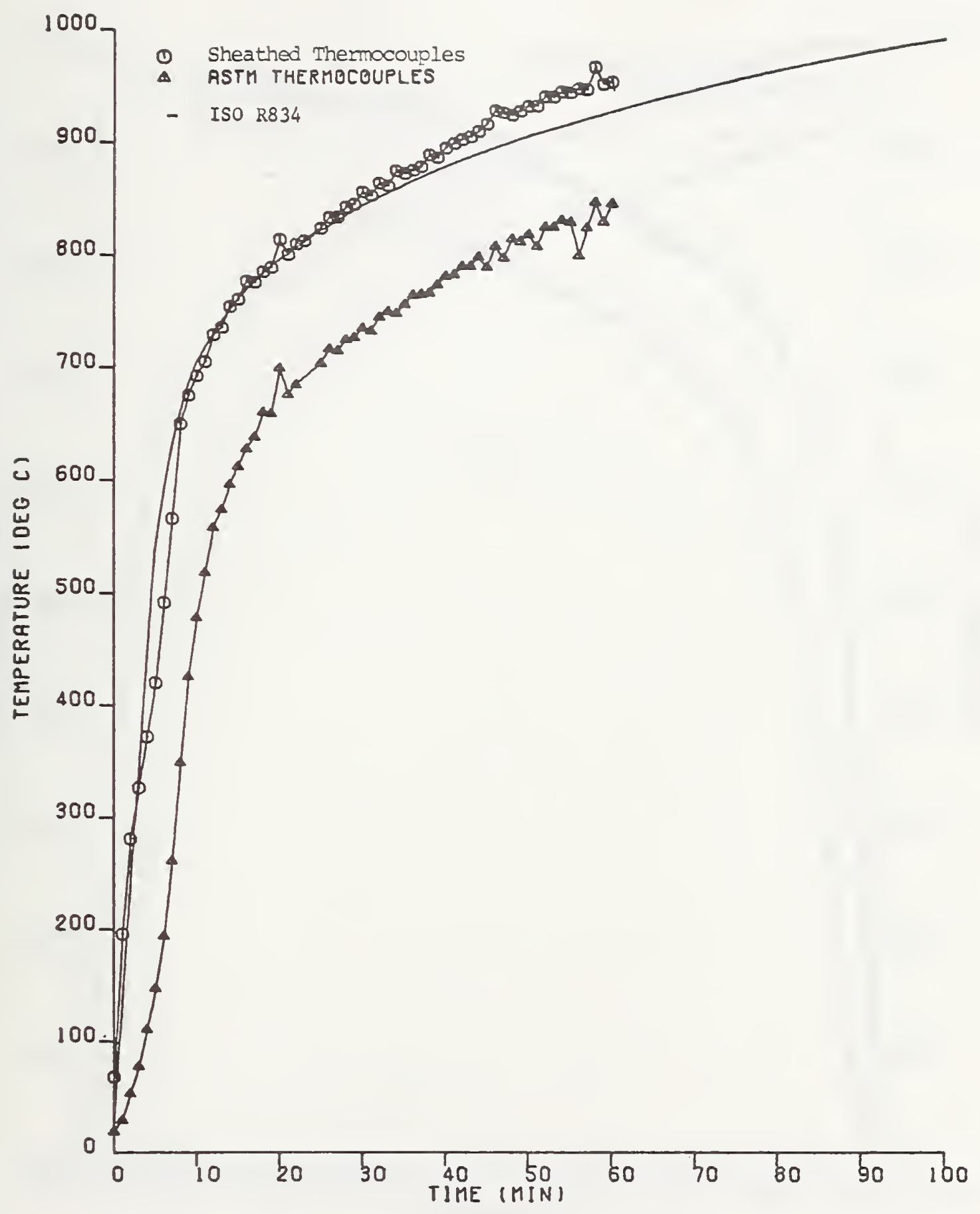

Figure 11. Furnace Temperatures in Test No. 1. 


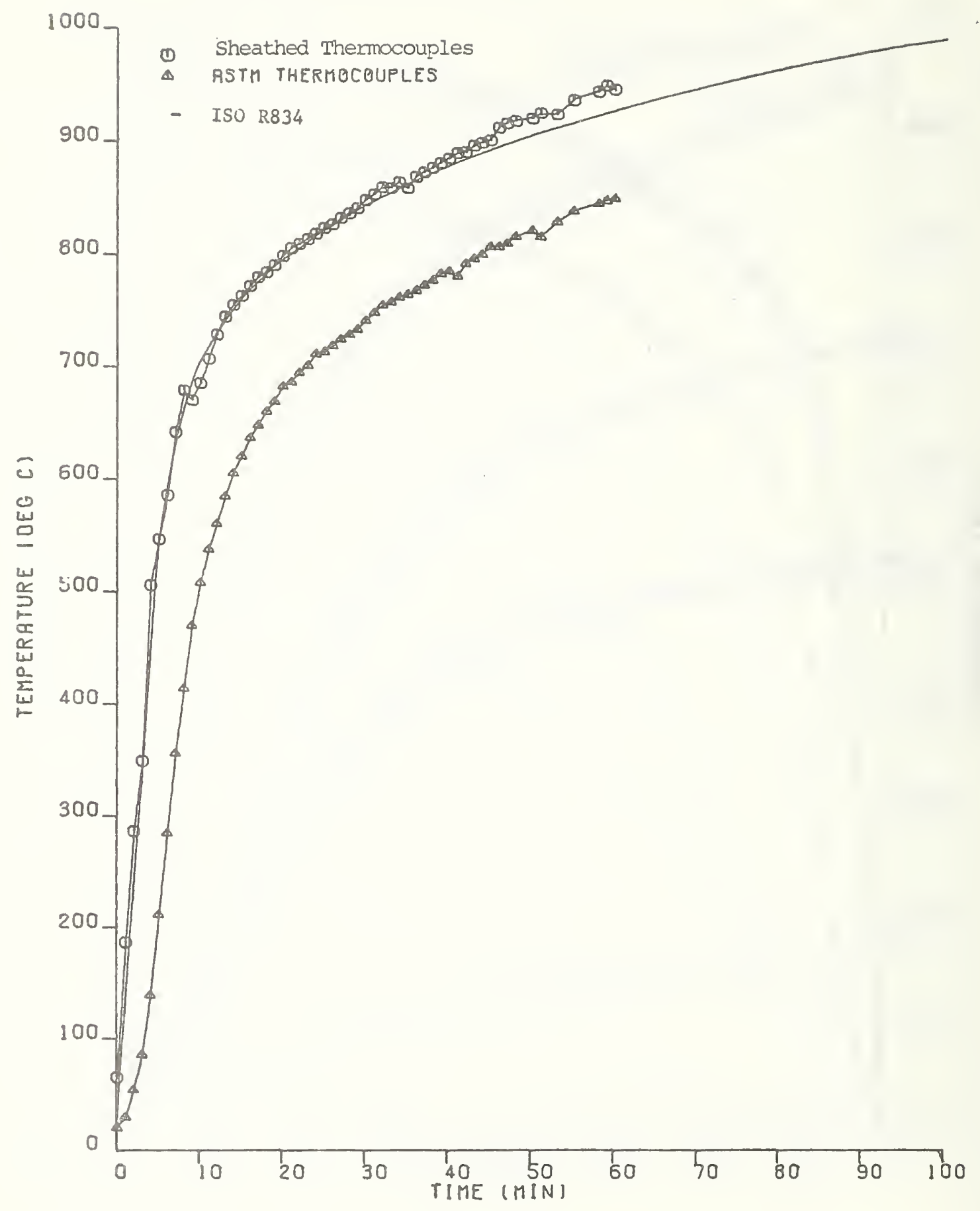

Figure 12. Furnace Temperatures in Test No. 2. 


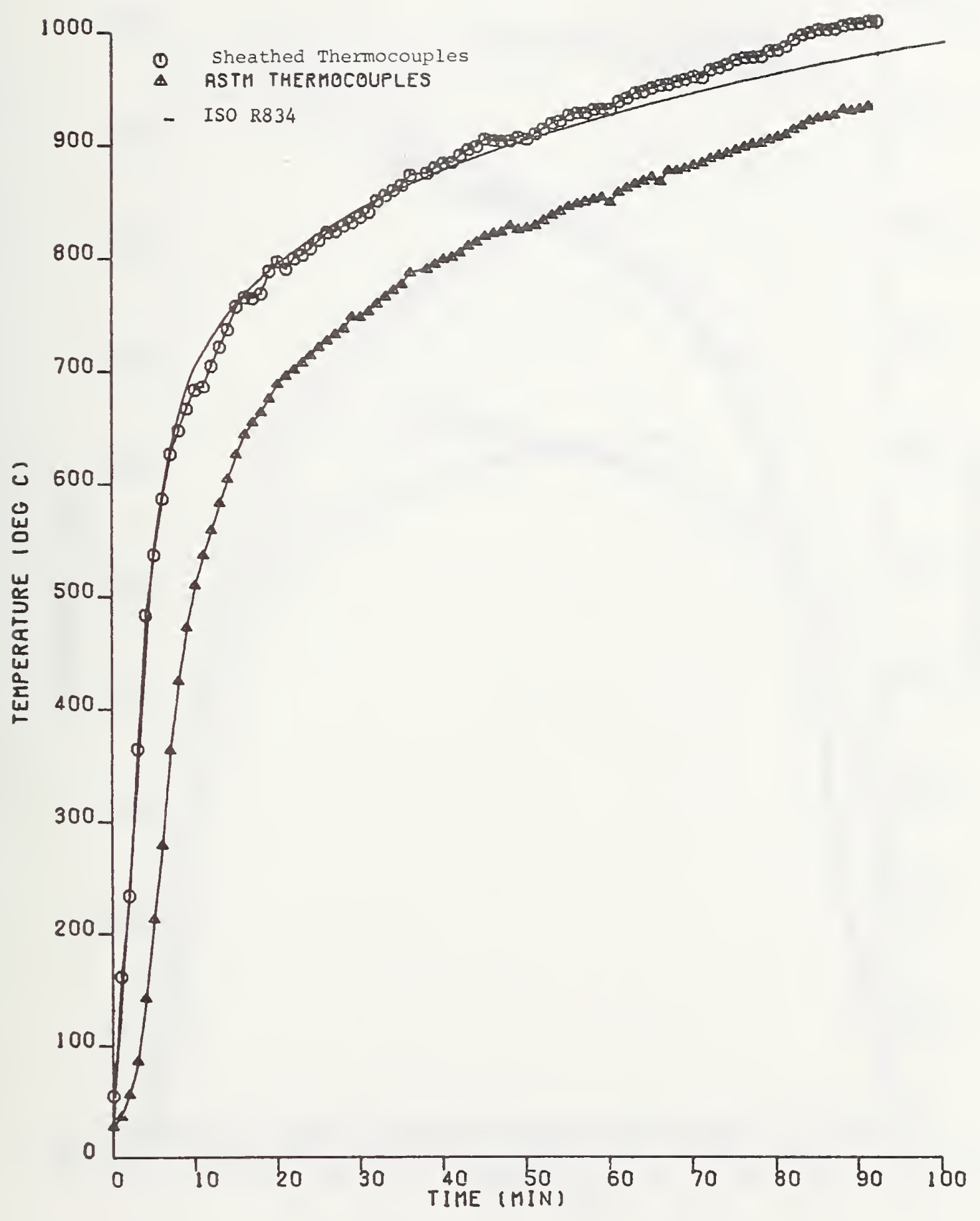

Figure 13. Furnace Temperatures in Test No. 3. 


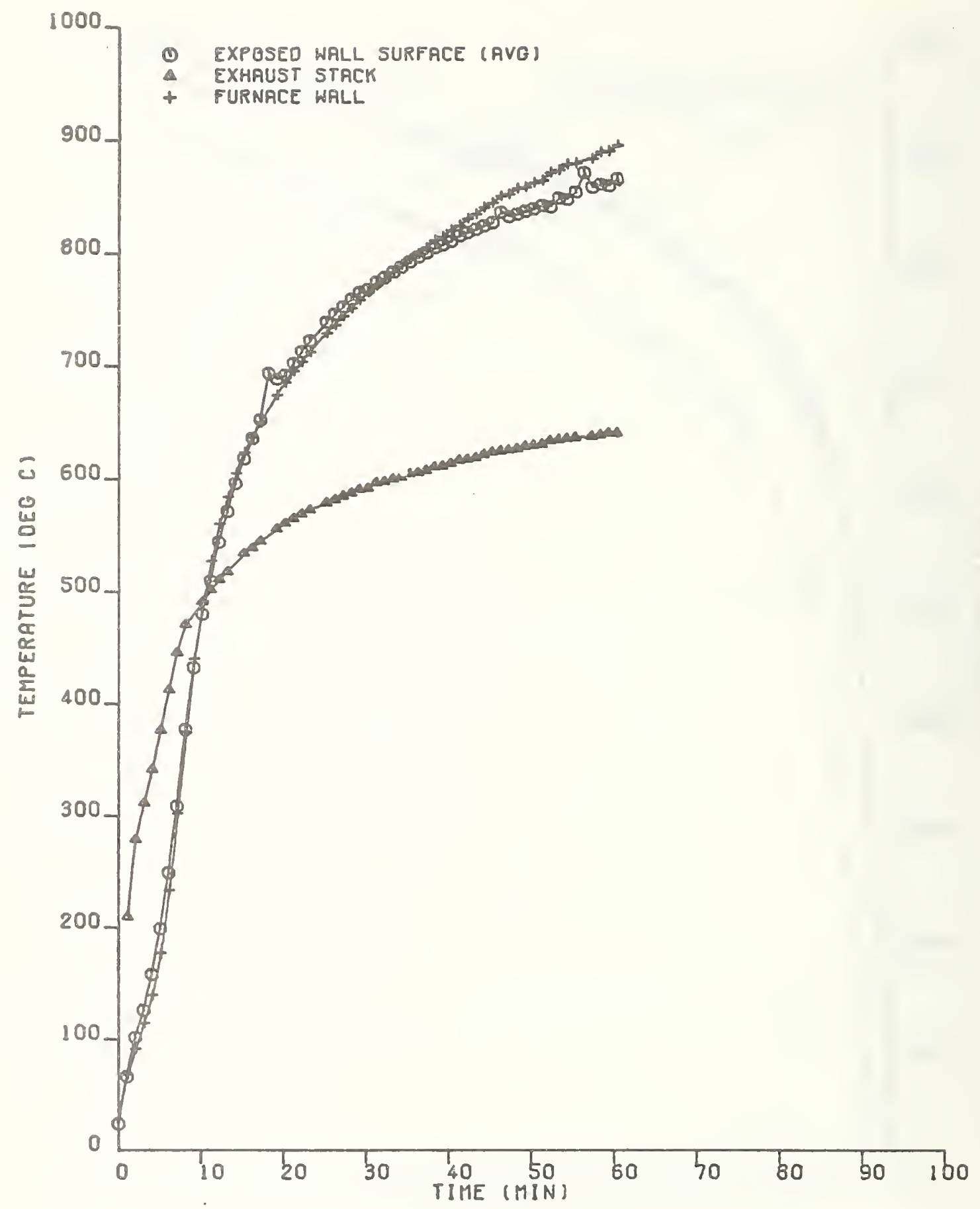

Figure 14. Stack and Wall Temperatures in Test No. 1. 


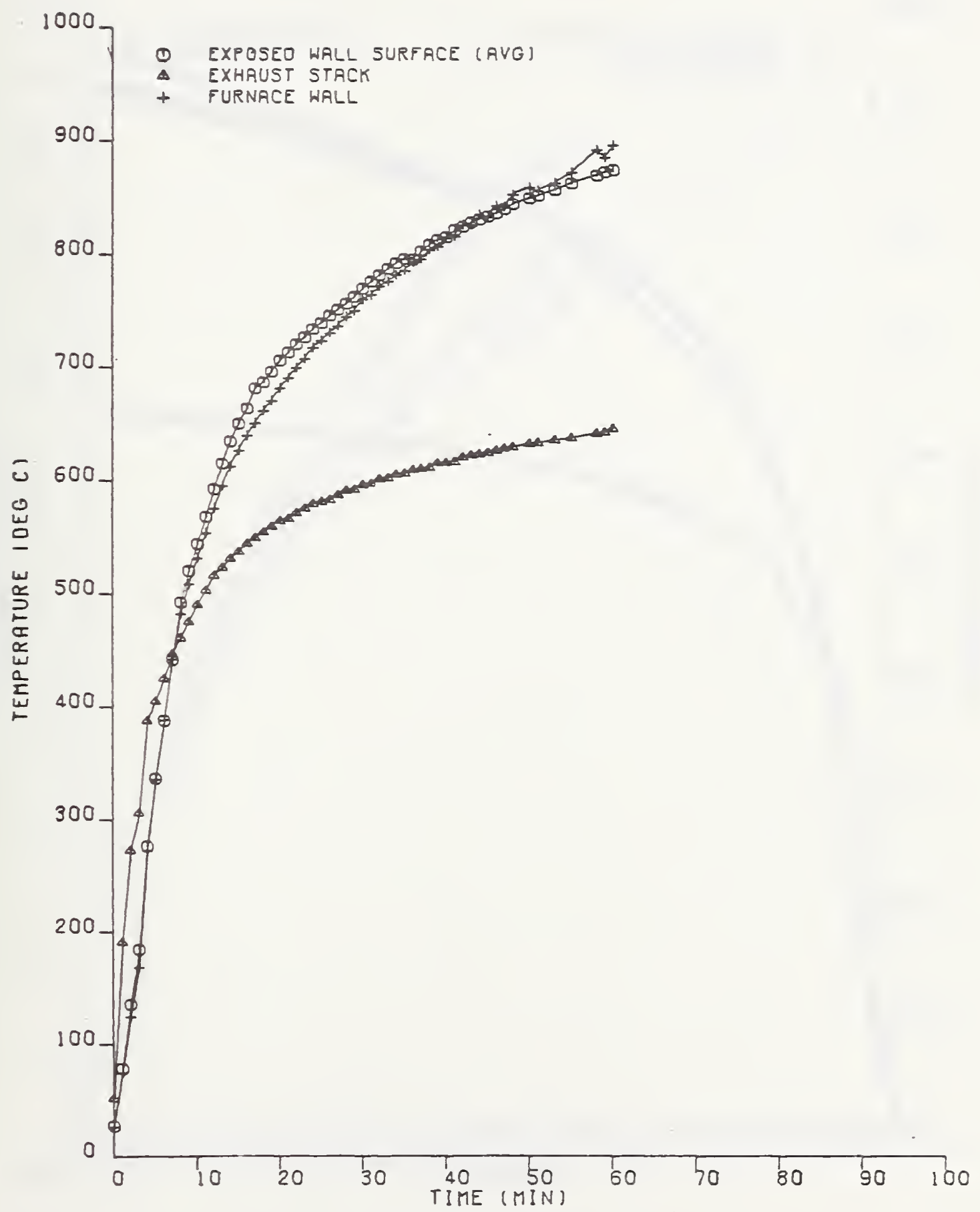

Figure 15. Stack and Wall Temperatures in Test No. 2.

27 


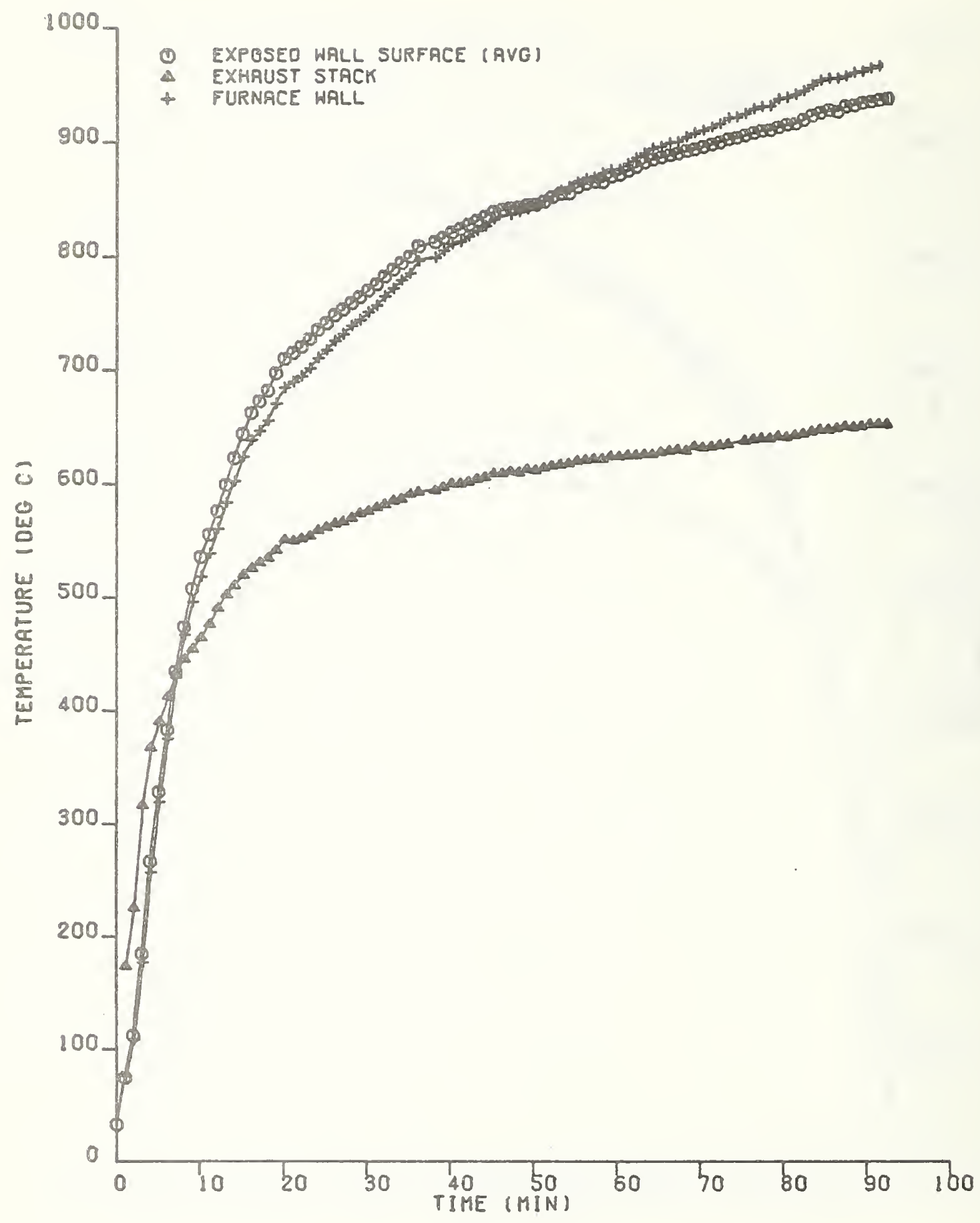

Figure 16. Stack and Wa11 Temperatures in Test No. 3. 


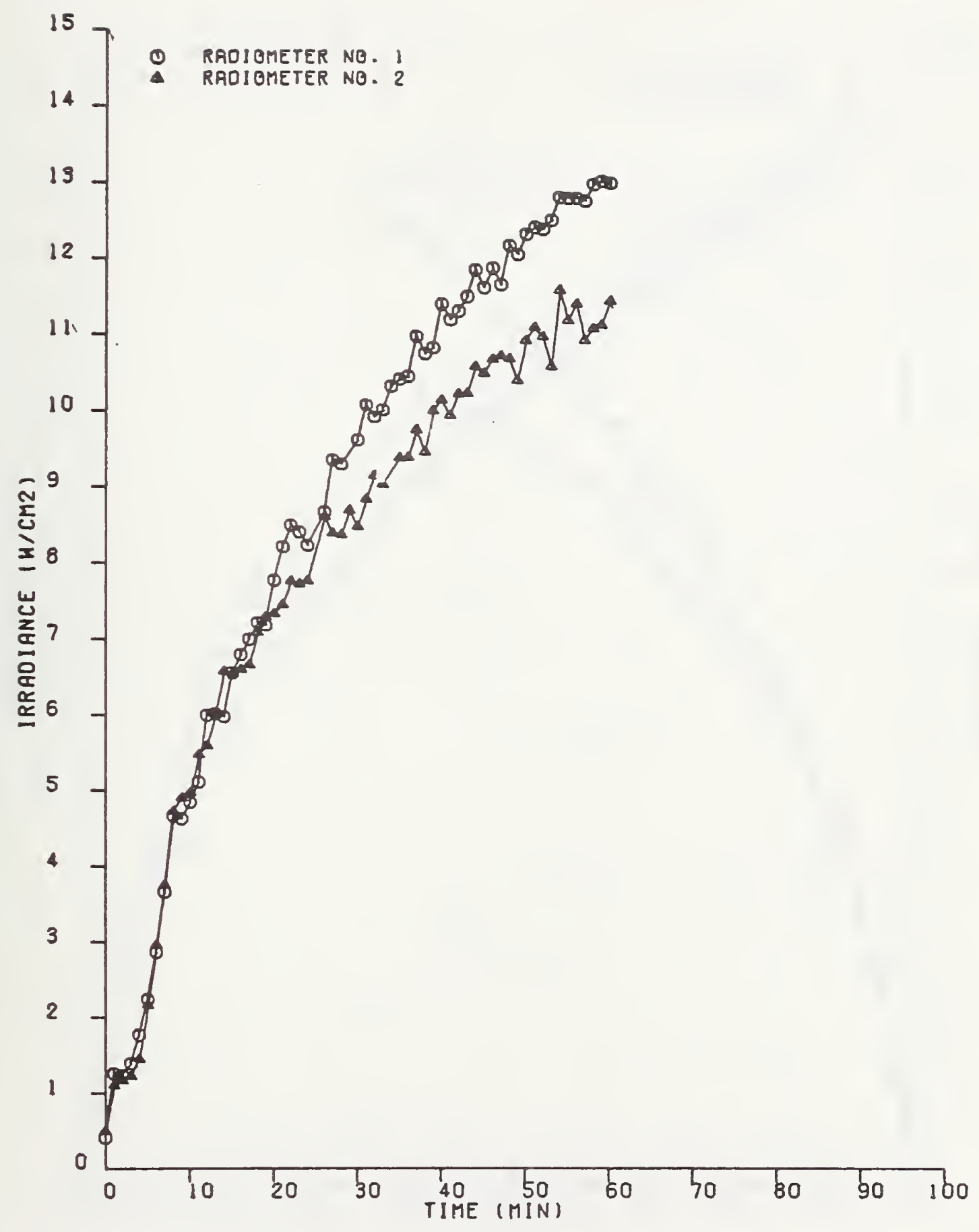

Figure 17. Radiometer Readings in Test No. 1. 


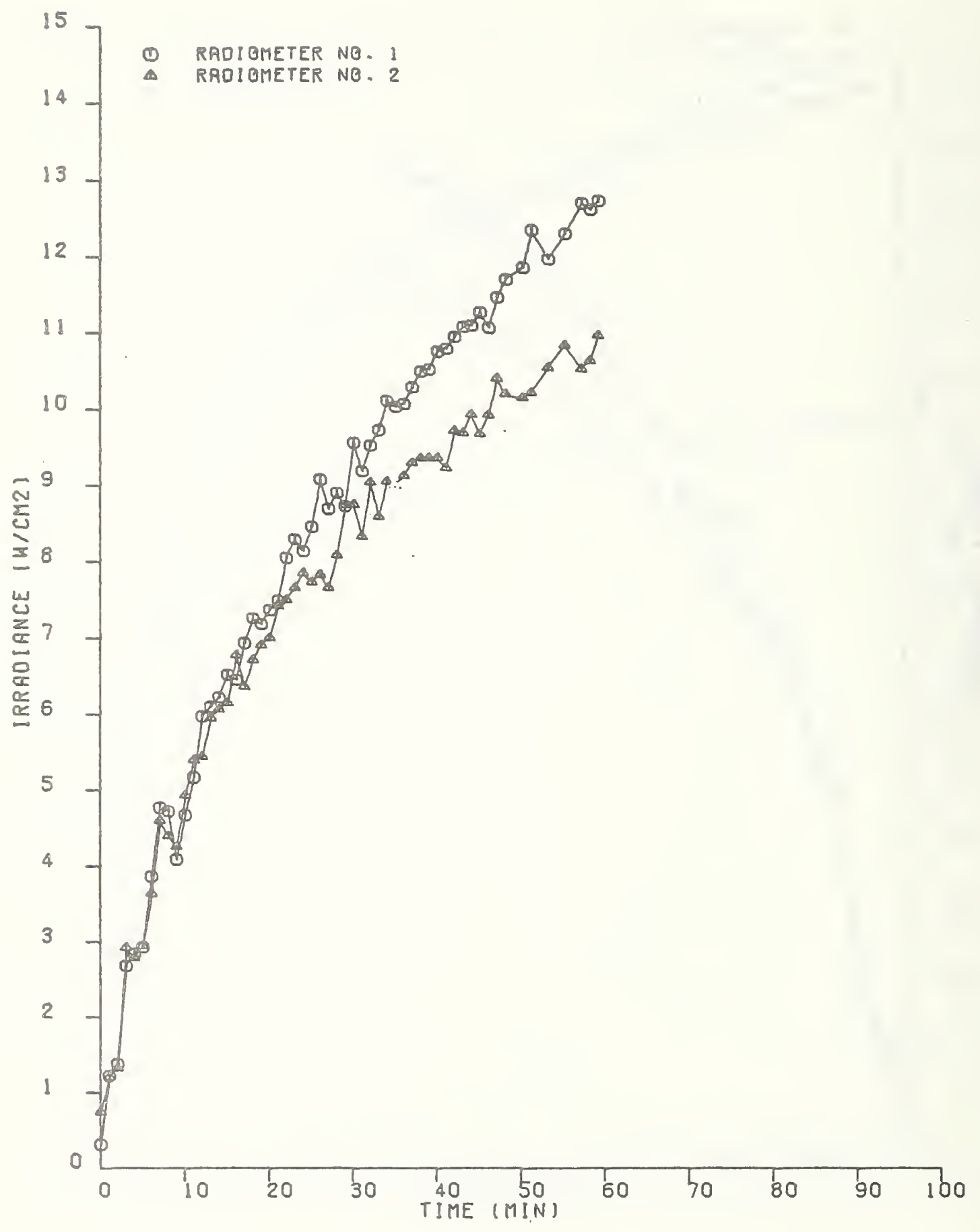

Figure 18. Radiometer Readings in Test No. 2. 


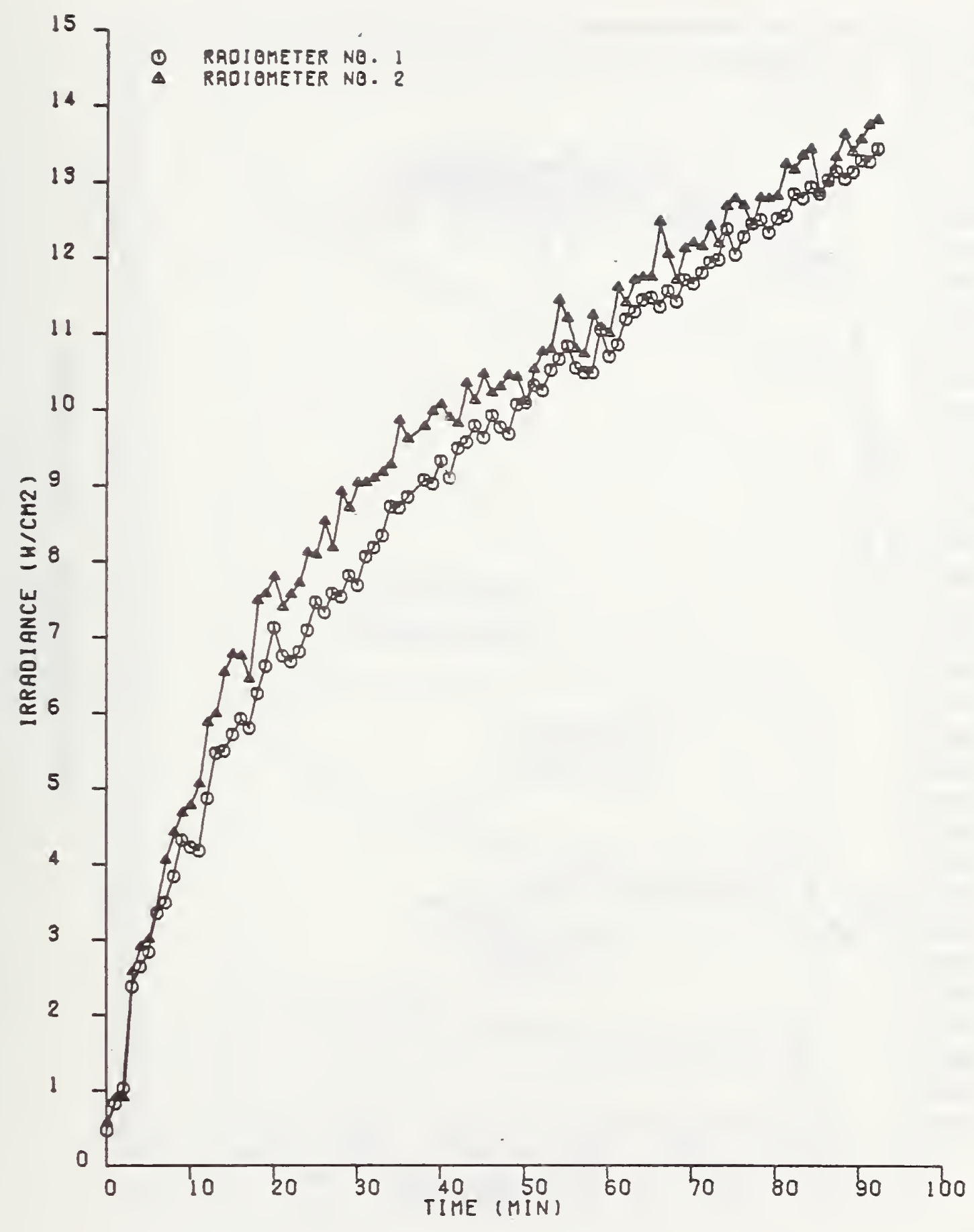

Figure 19. Radiometer Readings in Test No. 3. 


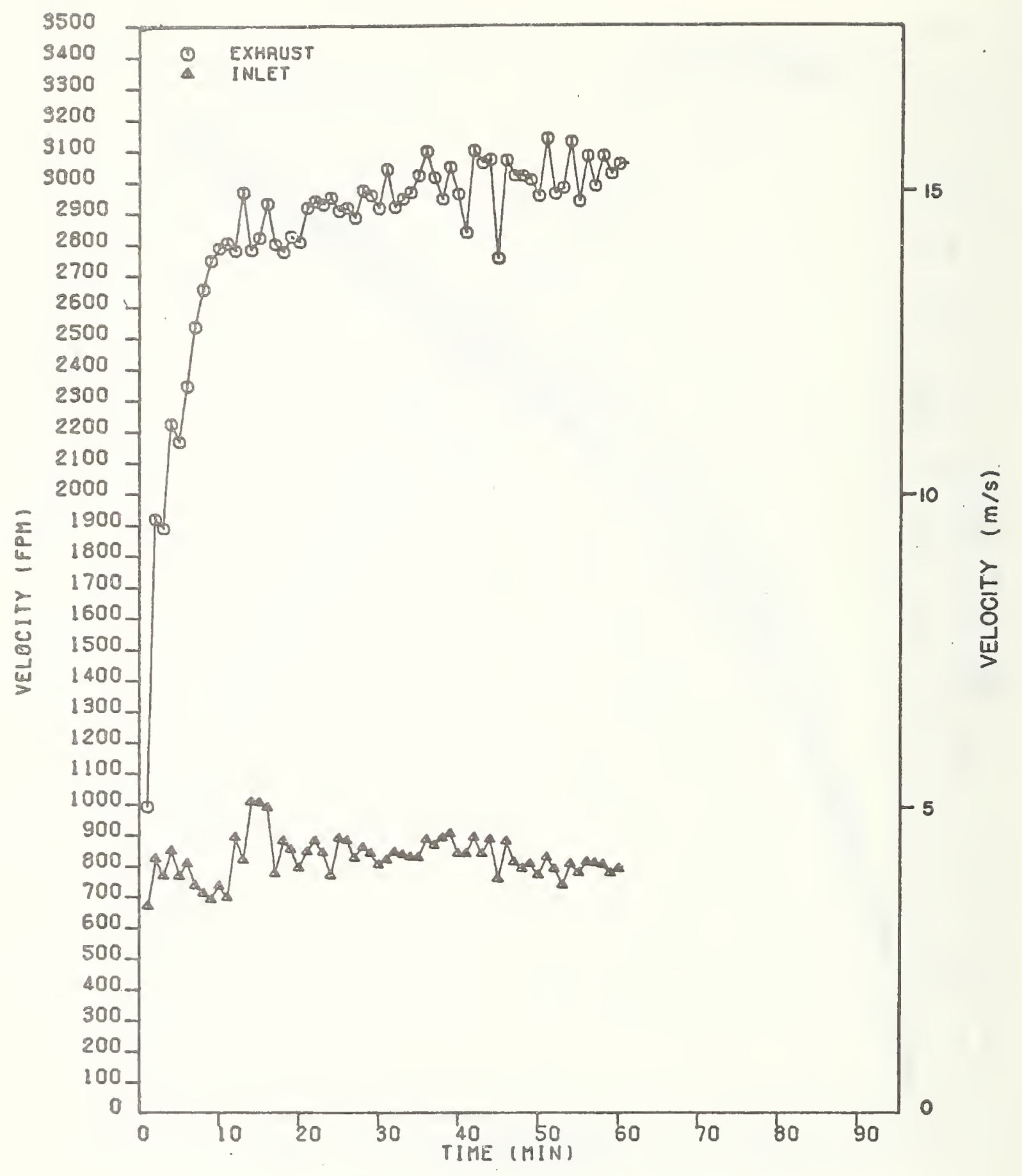

Figure 20. Inlet Air and Exhaust Gas Velocities in Test No. 1. 


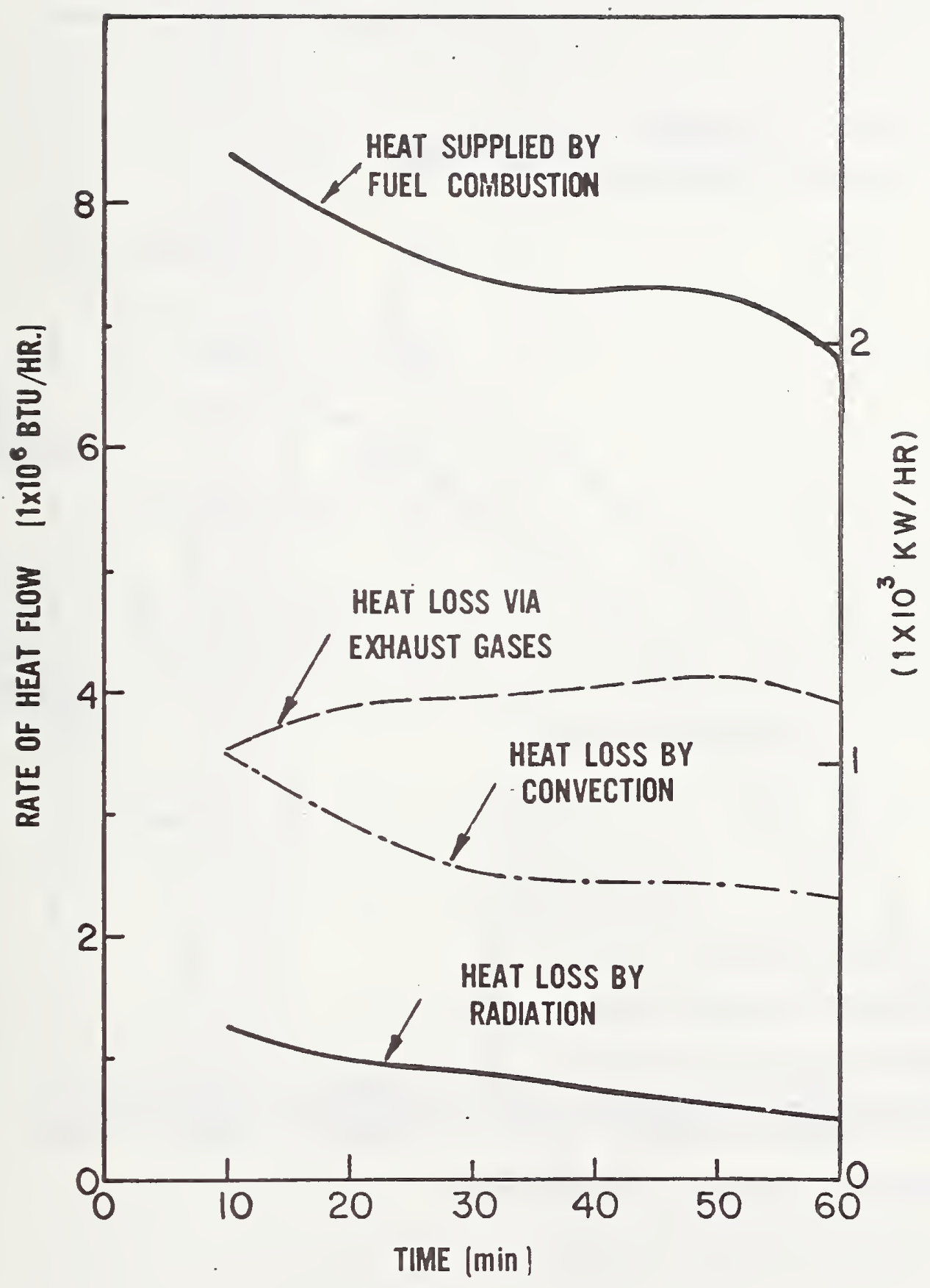

Figure 21. Calculated Heat Input and Output Curves for NBS Wall Furnace Using a Lightweight Masonry Block Test Wall (Test No. 1). 


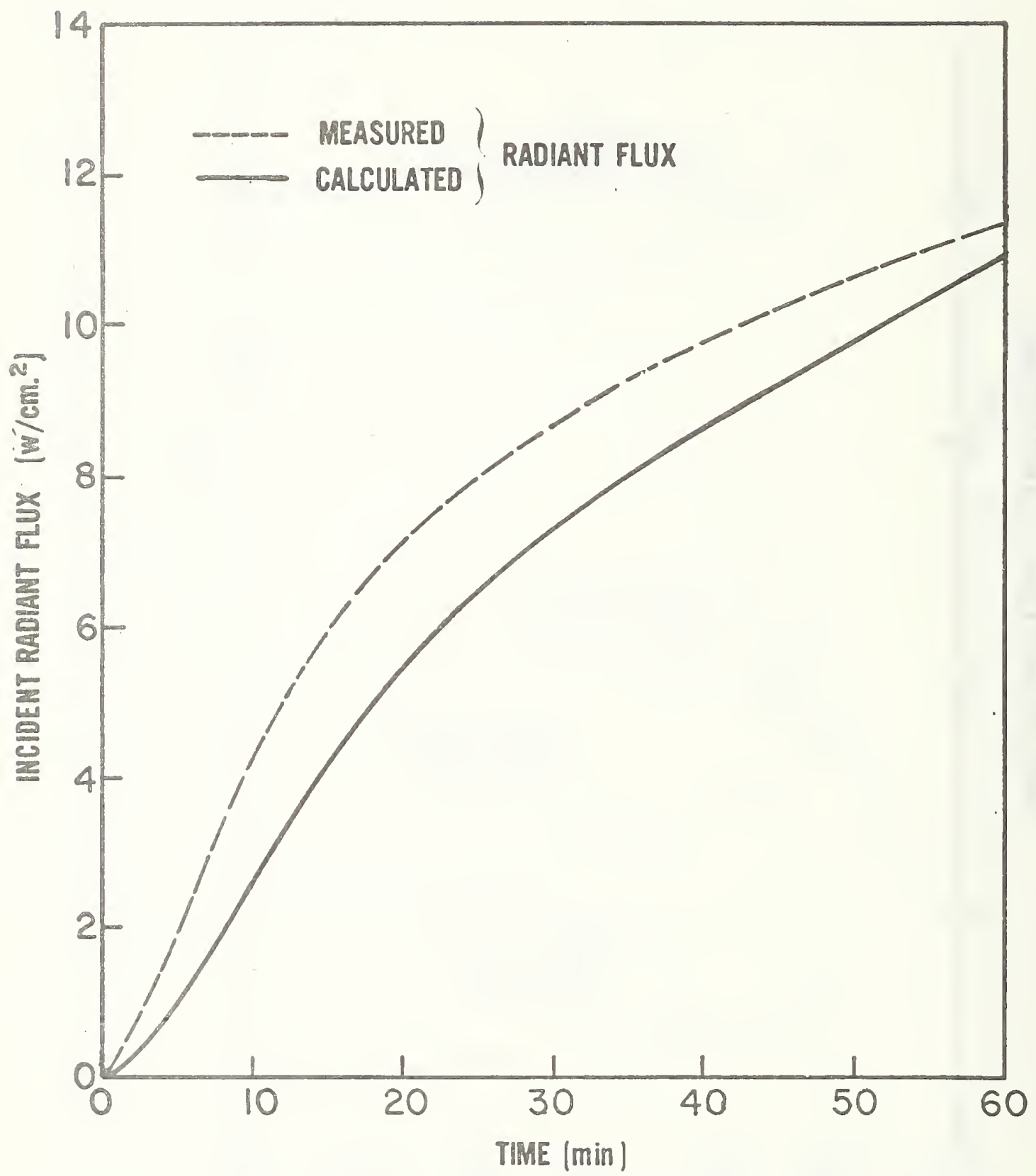

Figure 22. Comparison of Calculated Radiant Heat Flux Incident at Furnace Walls and Radiant Flux Measurement (R-2) on Test Wall for Test No. 1 . 


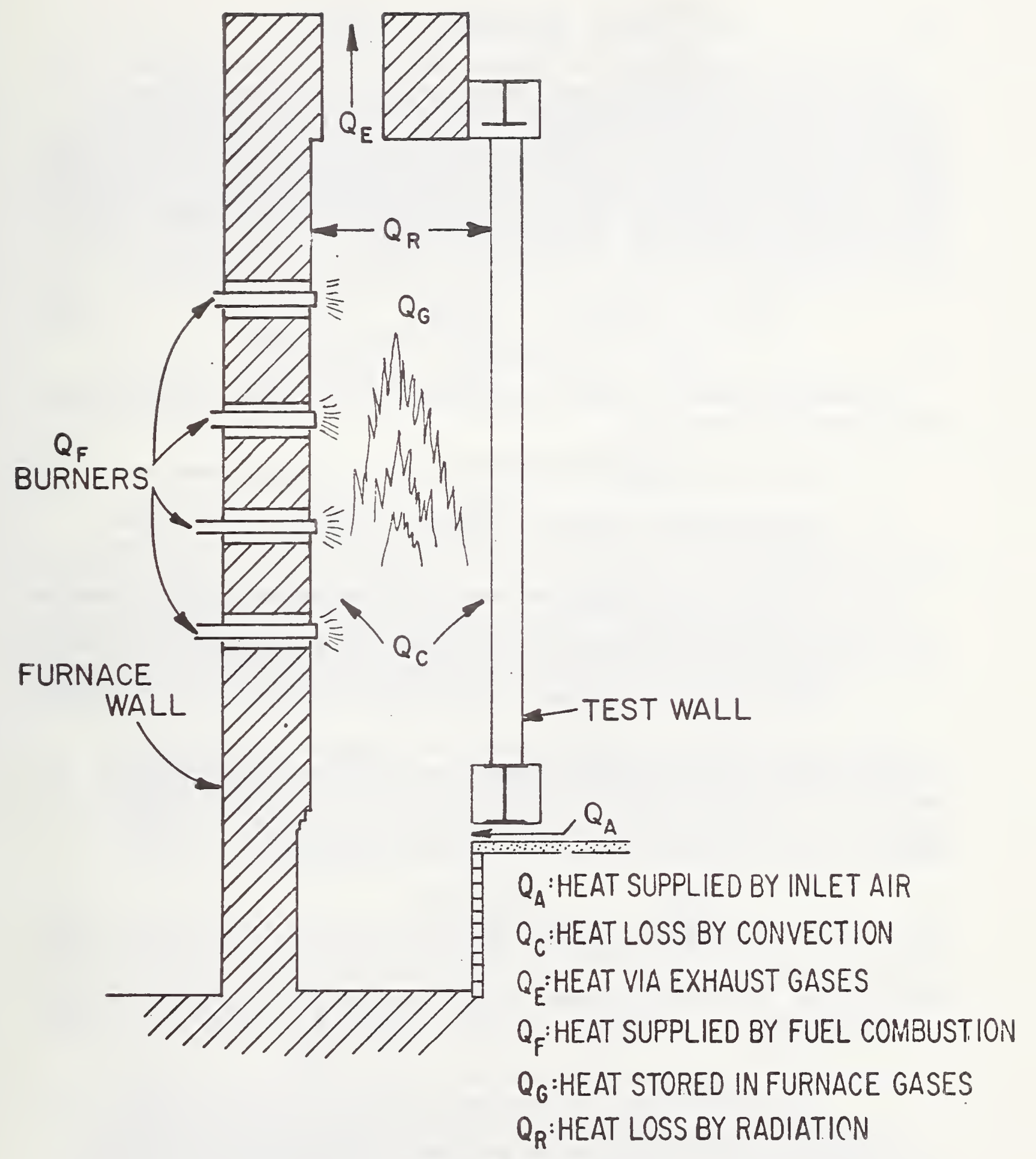

Figure 23. Schematic Diagram of Furnace and Heat Transfer. 
The law of conservation of energy applied to the test furnace, which is considered as a control volume, expresses the fact that the rate of increase of total energy contained in the furnace gases will equal the sum of (a) the net rate of energy transport into the system associated with the mass flow and (b) the rate of heat generation by fuel combustion, minus the rate of energy removal across the bounding surfaces. Accordingly a macroscopic energy balance equation for the test furnace illustrated in figure 23 can be written in the form:

$$
\frac{d E_{t}}{d t}=\sum\left(w_{i} H_{i}\right)_{i n}-\sum\left(w_{i} H_{i}\right)_{\text {out }}+Q_{F}-Q_{L}
$$

In order to make the analysis mathematically feasible, the following assumptions were made:

1. There is no temperature variation in the furnace gases.

2. A stoichiometric complete combustion process occurs in the furnace.

3. The heat loss by radiation through openings can be neglected.

4. The furnace walls and test specimen are gray-bodies, and the entire furnace walls have substantially uniform surface temperatures and can be assigned a single mean temperature.

The total energy accumulated within the furnace gases comprises internal, kinetic and potential energy, the last two of which may be neglected in comparison with the remaining one. The rate of energy stored in the furnace gases and the sensible heat supplied by inlet air and fuel were calculated from the following expressions:

$$
\begin{gathered}
\frac{d E_{t}}{d t}=V \rho_{M} C_{V} \frac{d\left(T_{M}-T_{I}\right)}{d t} \\
\sum\left(w_{i} H_{i}\right)_{i n}={ }_{w_{F}}\left(H_{F}^{\circ}+\int_{T_{0}}^{T_{T}} C_{F} d T\right)+w_{A}\left(H_{A}^{\circ}+\int_{T_{0}}^{T_{T}} C_{A} d T\right)
\end{gathered}
$$

The velocity and temperature of the inlet air and the volumetric flow rate of fuel into the furnace were measured throughout the test. The contributions of these two terms, which were evaluated in reference to standard conditions at a datum temperature of $15^{\circ} \mathrm{C}\left(60{ }^{\circ} \mathrm{F}\right)$, were found to amount to less than one percent of the total heat transfer supplied. Since these quantities were of negligible impact and were on opposite sides of the heat balance equation, equation 1 reduced to: 


$$
Q_{F}=\sum\left(w_{i} H_{i}\right)_{\text {out }}+Q_{L}
$$

The rate of heat provided by the fuel combustion was equal to the rate of fuel consumed multiplied by its net heating value. The composition of the exhaust gases can be determined either by direct experimental measurement or by calculation from air overall material balance for each chemical species present, based on the measured fuel gas composition and concentration of one of the component gases in the exhaust stream along with the assumption of complete combustion for the fuel gas reacted with air. The heat loss due to the venting of the exhaust gases was calculated from:

$$
\begin{aligned}
\sum\left(w_{i} H_{i}\right)_{\text {out }} & =\sum w_{i}\left(H_{i}^{\circ}+\int_{T_{0}}^{T_{E}} c_{i} d T\right) \\
w_{i} & =\left(\rho_{M} U_{E} A_{E}\right)\left(\frac{X_{i} M_{i}}{\Sigma X_{i} M_{i}}\right) .
\end{aligned}
$$

where

Heat loss to the bounding surfaces consisting of the test specimen and the walls of the test furnace occurred mainly by convection and radiation from the hot furnace gases. The radiation incident at the test specimen consisted of direct emission from the furnace gases, and radiative contribution from surrounding furnace walls through the gases. The net rates of radiation and convection losses to the test specimen can be expressed by

$$
\begin{aligned}
Q_{S}= & \sigma_{A_{S}} \varepsilon_{S}^{\prime}\left(\varepsilon_{M} T_{M}{ }^{4}-\alpha_{S} T_{S}{ }^{4}\right)+\sigma_{A_{S}} \varepsilon_{S} \varepsilon_{W}\left[\left(1-\alpha_{W}\right) T_{W}{ }^{4}-\left(1-\alpha_{S}\right) T_{S}{ }^{4}\right] \\
& +h_{S}\left(T_{M}-T_{S}\right)
\end{aligned}
$$

where $\alpha_{W}$ and $\alpha_{S}$ are the total absorptivities of the furnace gases, to be evaluated at the furnace wall and test specimen temperatures, respectively. [8] $A_{S}, \varepsilon_{S}^{\prime}, \varepsilon_{S}$ and $T_{S}$ are the surface area, effective surface emissivity, surface emissivity, and absolute surface temperature of the test specimen, respectively.

Similarly, the net rates of radiative and convective exchange for the furnace walls with furnace gases and the test specimen are

$$
\begin{aligned}
Q_{W}= & \sigma_{A_{W}} \varepsilon_{W}^{\prime}\left(\varepsilon_{M} T_{M}^{4}-\alpha_{W} T_{W}^{4}\right)+\alpha_{A_{S}} \varepsilon_{S} \varepsilon_{W}\left[\left(1-\alpha_{S}\right) T_{S}^{4}-\left(1-\alpha_{W}\right) T_{W}{ }^{4}\right] \\
& +h A_{W}\left(T_{M}-T_{W}\right)
\end{aligned}
$$


where $A_{W}$ and $T_{W}$ are the surface area and surface temperature of the furnace walls, respectively. $\varepsilon_{W}$ and $\varepsilon_{W}^{\prime}$ denote the surface emissivity and effective surface emissivity of the furnace walls, respectively.

A review of figure 14 showed that there was little variation between the surface temperatures of furnace walls and test specimen. Incorporating this information, the test specimen and furnace walls were treated as a single zone. Defining $Q_{B}$ to be the sum of $Q_{S}$ and $Q_{W}$, and combining equations 6 and 7 yields

$$
Q_{B}=Q_{R}+Q_{C}=\alpha A_{B} \varepsilon\left(\varepsilon_{M} T_{M}^{4}-\alpha_{B} T_{B}^{4}\right)+h A_{B}\left(T_{M}-T_{B}\right)
$$

A simplified equation describing the overall heat balance for the test furnace can be obtained by introducing the above relationship into equation 4. Thus,

$$
Q_{F}=\sum\left(w_{i} H_{i}\right)_{\text {out }}+\left(Q_{R}+Q_{C}\right)
$$

Both the total emissivity and absorptivity for the furnace gases were determined in accordance with the procedures recommended in the text [8] taking into account the concentrations of $\mathrm{CO}_{2}$ and $\mathrm{H}_{2} \mathrm{O}$ vapor, gas temperature, furnace geometry and size, and surface temperatures of furnace walls. A value of $\left(1+\varepsilon_{B}\right) / 2$ was used for the effective surface emissivity, $\varepsilon$, of the entire boundary walls. [8] The geometric beam length used in gas radiation calculation was equivalent to 4 times of the furnace volume divided by its internal surface area.

A11 parameters in equations 8 and 9 were either known or measured except for the convective heat transfer coefficient (h). By calculating al1 the other quantities, it was possible to determine the convective heat transfer coefficient. The above equations were solved at 10 minute time intervals from 10 to 60 minutes. A plot of the heat input and output terms in the overal1 heat balance equation is shown in figure 21 .

The net radiant heat flux density at a gray surface element of total emissivity $\varepsilon_{B}$ and at temperature $\mathrm{T}_{B}$ due to incidence of radiative heat flux $H_{B}$ coming from the surroundings was expressed by

$$
\frac{Q_{R}}{A_{B}}=\varepsilon_{B}\left(H_{B}-\sigma T_{B}{ }^{4}\right)
$$

Evaluation of the radiant flux incident at furnace walls at any time was possible using the above equation along with known or measured values for a11 the other parameters. Figure 22 was derived from these results. 
APPENDIX B. A LIST OF ASSUMED PROPERTIES FOR TEST FURNACE

Furnace Walls:

Heat Capacity: $0.84 \mathrm{~J} / \mathrm{g}-{ }^{\circ} \mathrm{K}\left(0.2 \mathrm{Btu} / 1 \mathrm{~b}-{ }^{\circ} \mathrm{F}\right)$

Thermal Conductivity: $0.52 \mathrm{~W} / \mathrm{m}-{ }^{\circ} \mathrm{K}\left(0.3 \mathrm{Btu} / \mathrm{hr}-\mathrm{ft}-{ }^{\circ} \mathrm{F}\right)$

Density: $1.25 \mathrm{~g} / \mathrm{cm}^{3}\left(78 \mathrm{lb} / \mathrm{ft}^{3}\right)$

Surface Emissivity $\left(\varepsilon_{B}\right): 0.8$

Effective Surface Emissivity $(\varepsilon): 0.9$

Furnace:

Total Volume (V): $14.2 \mathrm{~m}^{3}\left(492 \mathrm{ft}^{3}\right)$

Total Internal Surface Area $\left(A_{B}\right): 55.7 \mathrm{~m}^{2}\left(600 \mathrm{ft}^{2}\right)$ 
NBS.114A (REV. 7-73)

\begin{tabular}{|c|c|c|}
\hline $\begin{array}{l}\text { 1. PUBI.LCATION OR REPORT NO. } \\
\text { NBSIR } 75-794\end{array}$ & $\begin{array}{l}\text { 2. Gov't Accession } \\
\text { No. }\end{array}$ & 3. Recipient's Accession No. \\
\hline \multirow{2}{*}{\multicolumn{2}{|c|}{$\begin{array}{l}\text { Heat Transfer in Furnaces for CIB Cooperative } \\
\text { Program and Heat Balance Analysis of Wall } \\
\text { Furnace }\end{array}$}} & $\begin{array}{l}\text { 5. Publication Date } \\
\text { November }\end{array}$ \\
\hline & & 6. Performing Organization Code \\
\hline \multicolumn{2}{|l|}{$\begin{array}{l}\text { 7. AUTHOR(S) } \\
\text { J. B. Fang and J. T. Scott }\end{array}$} & $\begin{array}{l}\text { 8. Performing Organ. Repo' No. } \\
\text { NBSIR 75-794 }\end{array}$ \\
\hline \multicolumn{2}{|l|}{ 9. PERFORMING ORGANIZATION NAME AND ADDRESS } & $\begin{array}{c}\text { 10. Project/Task/Work Unit No. } \\
4926389\end{array}$ \\
\hline \multicolumn{2}{|l|}{$\begin{array}{l}\text { NATIONAL BUREAU OF STANDARDS } \\
\text { DEPARTMENT OF COMMERCE } \\
\text { WASHINGTON, D.C. } 20234\end{array}$} & 11. Contract/Grant No. \\
\hline \multirow{3}{*}{\multicolumn{2}{|c|}{ 12. Sponsoring Organization Name and Complete Address (Street, City, State, ZIP) }} & $\begin{array}{l}\text { 13. Type of Report \& Period } \\
\text { Covered }\end{array}$ \\
\hline & & Fina 1 \\
\hline & & 14. Sponsoring Agency Code \\
\hline
\end{tabular}

15. SUPPLEMEN'TARY NOTES

16. ABSTRACT (A 200-word or less factual summary of most significant information. If document includes a significant bibliography or literature survey, mention it here.)

Tests were conducted in the NBS wall panel furnace as part of a CIB international cooperative program to measure and compare heat transfer in fire endurance furnaces. Additionally, a heat balance analysis showed that a cellular concrete block wall specimen absorbed more heat by convection than by radiation. The rate of radiant heat transfer was found to decrease slowly, while the furnace exhaust heat loss increased during the test from 42 to 58 percent of the heat output. The calculated radiant heat fluxes incident at furnace walls was found to be somewhat lower than the experimental values measured at the test wall.

17. KEY WORDS (six to twelve entries; alphabetical order; capitalize only the first letter of the first key word unless a proper name; separated by semicolons) Fire resistance ratings; fire test furnace; heat balance; heat transfer; temperature-time curve.

18. AVAILABILITY $\quad$ Unlimited

[ For Official Distribution. Do Not Release to NTIS

$\square$ Order From Sup. of Doc., U.S. Government Printing Office Wa shington, D.C. 20402 , SD Cat. No.C13

X. Otdet From National Iechnical tnfotnation service (ivTIS) Springfield, Virginia 22151

\begin{tabular}{|l|c|}
\hline $\begin{array}{l}\text { 19. SECURITY CLASS } \\
\text { (THIS REPURT) }\end{array}$ & $\begin{array}{c}\text { 21. NO. OF PAGES } \\
\text { UNCL ASSIFIED }\end{array}$ \\
\hline $\begin{array}{l}\text { 20. SECURITY CLASS } \\
\text { (THIS PAGE) }\end{array}$ & $\begin{array}{c}\text { 22. Price } \\
\$ 3.75\end{array}$ \\
UNCLASSIFIED & $\$ 3$ \\
\hline
\end{tabular}

